Article

\title{
New Coordination Polymers of Zinc(II), Copper(II) and Cadmium(II) with 1,3-Bis(1,2,4-triazol-4-yl)adamantane
}

\author{
Nertil Xhaferaj ${ }^{1,2}$, Aurel Tăbăcaru ${ }^{3, *}\left(\mathbb{D}\right.$, Marco Moroni $^{4}$, Ganna A. Senchyk ${ }^{5}$, \\ Kostiantyn V. Domasevitch ${ }^{5}$, Claudio Pettinari ${ }^{2,6}$ 迥 and Simona Galli ${ }^{4,7, *}$ \\ 1 Department of Food Technology, Faculty of Food and Biotechnology, Agricultural University of Tirana, \\ Kodër Kamëz, SH1, 1000 Tirana, Albania; nertil.xhaferaj@gmail.com \\ 2 School of Pharmacy, University of Camerino, Via S. Agostino 1, 62032 Camerino, Italy; \\ claudio.pettinari@unicam.it \\ 3 Department of Chemistry, Physics and Environment, Faculty of Sciences and Environment, \\ “Dunarea de Jos" University of Galati, 111 Domneasca Street, 800201 Galati, Romania \\ 4 Dipartimento di Scienza e Alta Tecnologia, Università deli Studi dell'Insubria, Via Valleggio 11, \\ 22100 Como, Italy; mmoroni@studenti.uninsubria.it \\ 5 Inorganic Chemistry Department, Taras Shevchenko National University of Kyiv, 64 Volodimirska Street, \\ 01033 Kyiv, Ukraine; senchyk.ganna@gmail.com (G.A.S.); dk@univ.kiev.ua (K.V.D.) \\ 6 Istituto di Chimica dei Composti Organometallici (ICCOM-CNR), Via Madonna del Piano 10, \\ 50019 Sesto Fiorentino, Italy \\ 7 Consorzio Interuniversitario Nazionale per la Scienza e Tecnologia dei Materiali, Via Giusti 9, \\ 50121 Firenze, Italy \\ * Correspondence: aurel.tabacaru@ugal.ro (A.T.); simona.galli@uninsubria.it (S.G.)
}

Received: 16 October 2020; Accepted: 30 October 2020; Published: 6 November 2020

\begin{abstract}
The new coordination polymers (CPs) $\left[\mathrm{Zn}\left(\operatorname{tr}_{2} \mathrm{ad}\right) \mathrm{Cl}_{2}\right]_{n},\left\{\left[\mathrm{Cu}\left(\operatorname{tr}_{2} \mathrm{ad}\right) \mathrm{Cl}\right] \mathrm{Cl} \cdot 4 \mathrm{H}_{2} \mathrm{O}\right\}_{n}$, $\left[\mathrm{Cd}_{2}\left(\operatorname{tr}_{2} \mathrm{ad}\right) \mathrm{Cl}_{4}\right]_{n},\left\{\left[\mathrm{Cu}\left(\operatorname{tr}_{2} \mathrm{ad}\right)\left(\mathrm{NO}_{3}\right)\right]\left(\mathrm{NO}_{3}\right)\right\}_{n}$ and $\left\{\left[\mathrm{Cd}\left(\operatorname{tr}_{2} \mathrm{ad}\right)\left(\mathrm{NO}_{3}\right)\right]\left(\mathrm{NO}_{3}\right) \cdot \mathrm{H}_{2} \mathrm{O}\right\}_{n}$ were obtained in the form of air- and moisture-stable microcrystalline powders by the solvothermal reactions of zinc(II), copper(II) and cadmium(II) chlorides or nitrates with the ligand 1,3-bis(1,2,4-triazol-4-yl)adamantane $\left(\operatorname{tr}_{2} \mathrm{ad}\right)$. Investigation of the thermal behaviour assessed the thermal stability of these CPs, with $\left[\mathrm{Cd}_{2}\left(\operatorname{tr}_{2} \mathrm{ad}\right) \mathrm{Cl}_{4}\right]_{n}$ starting to decompose only around $365^{\circ} \mathrm{C}$. As retrieved by powder X-ray diffraction, while $\left[\mathrm{Zn}\left(\operatorname{tr}_{2} \mathrm{ad}\right) \mathrm{Cl}_{2}\right]_{n}$ features 1-D chains along which the metal centre shows a tetrahedral geometry and the spacer is exo-bidentate, the other CPs contain 2-D double-layers in which the metal ions possess an octahedral stereochemistry and the linker is exo-tetradentate. A comparative structural analysis involving known coordination compounds containing the $\operatorname{tr}_{2}$ ad ligand enabled us to disclose (i) the versatility of the ligand, as far as the coordination modes are concerned; (ii) the variability in crystal structure dimensionality, ranging from 1-D to 3-D; (iii) the fact that, to the best of our knowledge, $\left[\mathrm{Zn}\left(\operatorname{tr}_{2} \mathrm{ad}\right) \mathrm{Cl}_{2}\right]_{n}$ is the first $\mathrm{Zn}^{\mathrm{II}}$-based CP containing the $\operatorname{tr}_{2}$ ad spacer.
\end{abstract}

Keywords: coordination polymers; poly(azolate) spacers; 1,3-bis(1,2,4-triazol-4-yl)adamantane; zinc; copper; cadmium; crystal structure

\section{Introduction}

Since the discovery that metal ions and organic ligands can act as connectors and spacers, respectively, to generate infinite frameworks [1], the chemistry of coordination polymers (CPs) [2-5], including the subclass of metal-organic frameworks (MOFs) [6-10], has recorded a rapid growth, due to the plethora of functional properties they were found to possess. One of the main advantages of CPs 
and MOFs is the possibility to modulate their chemical composition, crystal structure and functional properties through a modification of the metal ion and/or the organic spacer. In view of their potential applications, CPs and MOFs appear as interesting platforms which may offer sustainable solutions in fields of major economical, technological and environmental importance, e.g., gas storage and separation [11], catalysis [12], luminescence [13,14], conductivity [15], magnetism [16], sensing [17-19] and biomedicine [20]. The successful preparation of CPs has generally relied on organic ligands from the class of poly(carboxylic) acids [21-23], pyrazines and bipyridines [21-24], phosphonic acids [25] and poly(azoles) [26-28].

Among the nitrogen-donor ligands from the class of poly(azoles), attention has been paid also to 1,2,4-triazolyl derivatives, due to their electron-donating ability and rich coordination chemistry. As a representative example, they can provide the $N^{1}, N^{2}$-bridging between two adjacent metal ions [29] in the same manner as pyrazolates do [30]. Based on the coordination modes they can adopt, 1,2,4-triazolyl ligands have been exploited in building up polynuclear and polymeric coordination compounds [31-35]. This is also the case of the ditopic ligand 1,3-bis(1,2,4-triazol-4-yl)adamantane ( $\operatorname{tr}_{2}$ ad, Scheme 1$)$ which, although at present less explored, provides an attractive platform for crystal engineering.

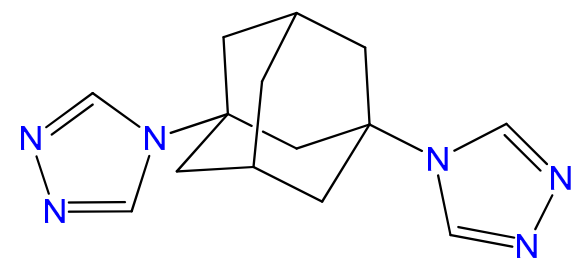

Scheme 1. Molecular structure of 1,3-bis(1,2,4-triazol-4-yl)adamantane ( $\left.\operatorname{tr}_{2} \mathrm{ad}\right)$.

Aiming at enlarging and diversifying the library of $\operatorname{tr}_{2}$ ad-based coordination frameworks, we report hereafter on the synthesis, thermal behavior and structural characterization of the five new compounds $\left[\mathrm{Zn}\left(\operatorname{tr}_{2} \mathrm{ad}\right) \mathrm{Cl}_{2}\right]_{n},\left\{\left[\mathrm{Cu}\left(\operatorname{tr}_{2} \mathrm{ad}\right) \mathrm{Cl}\right] \mathrm{Cl} \cdot 4 \mathrm{H}_{2} \mathrm{O}\right\}_{n},\left[\mathrm{Cd}_{2}\left(\operatorname{tr}_{2} \mathrm{ad}\right) \mathrm{Cl}_{4}\right]_{n},\left\{\left[\mathrm{Cu}\left(\operatorname{tr}_{2} \mathrm{ad}\right)\left(\mathrm{NO}_{3}\right)\right]\left(\mathrm{NO}_{3}\right)\right\}_{n}$ and $\left\{\left[\mathrm{Cd}\left(\operatorname{tr}_{2} \mathrm{ad}\right)\left(\mathrm{NO}_{3}\right)\right]\left(\mathrm{NO}_{3}\right) \cdot \mathrm{H}_{2} \mathrm{O}\right\}_{n}$. The crystal and molecular structures of the anhydrous and trihydrate $\mathrm{tr}_{2}$ ad ligand are also described.

\section{Results and Discussion}

\subsection{Synthesis and Preliminary Characterization}

A detailed description of the synthesis of the $\operatorname{tr}_{2}$ ad ligand, including analytical details on the intermediates never reported before, is provided in the Supporting Information.

Several screening reactions, involving the adoption of synthetic conditions differing in solvent, metal-to-ligand ratio, temperature, and/or time, were carried out in order to successfully obtain microcrystalline batches of the $\operatorname{tr}_{2}$ ad-based CPs $\left[\mathrm{Zn}\left(\operatorname{tr}_{2} \mathrm{ad}\right) \mathrm{Cl}_{2}\right]_{n},\left\{\left[\mathrm{Cu}\left(\operatorname{tr}_{2} \mathrm{ad}\right) \mathrm{Cl}\right] \mathrm{Cl} \cdot 4 \mathrm{H}_{2} \mathrm{O}\right\}_{n},\left[\mathrm{Cd}_{2}\left(\operatorname{tr}_{2} \mathrm{ad}\right) \mathrm{Cl}_{4}\right]_{n}$, $\left\{\left[\mathrm{Cu}\left(\operatorname{tr}_{2} \mathrm{ad}\right)\left(\mathrm{NO}_{3}\right)\right]\left(\mathrm{NO}_{3}\right)\right\}_{n}$ and $\left\{\left[\mathrm{Cd}\left(\operatorname{tr}_{2} \mathrm{ad}\right)\left(\mathrm{NO}_{3}\right)\right]\left(\mathrm{NO}_{3}\right) \cdot \mathrm{H}_{2} \mathrm{O}\right\}_{n}$. Scheme 2 shows the synthetic conditions fruitfully used for their isolation.

Compounds $\left[\mathrm{Zn}\left(\operatorname{tr}_{2} \mathrm{ad}\right) \mathrm{Cl}_{2}\right]_{n}$ and $\left\{\left[\mathrm{Cu}\left(\operatorname{tr}_{2} \mathrm{ad}\right) \mathrm{Cl}\right] \mathrm{Cl} \cdot 4 \mathrm{H}_{2} \mathrm{O}\right\}_{n}$ were isolated by carrying out a solvothermal reaction among zinc(II) chloride dihydrate and anhydrous copper(II) chloride, respectively, and $\operatorname{tr}_{2}$ ad in the 2:1 molar ratio $\left(\mathrm{DMF}, 150^{\circ} \mathrm{C}, 24 \mathrm{~h}\right)$. Also, the formation of compounds $\left[\mathrm{Cd}_{2}\left(\operatorname{tr}_{2} \mathrm{ad}\right) \mathrm{Cl}_{4}\right]_{n}$, $\left\{\left[\mathrm{Cu}\left(\operatorname{tr}_{2} \mathrm{ad}\right)\left(\mathrm{NO}_{3}\right)\right]\left(\mathrm{NO}_{3}\right)\right\}_{n}$ and $\left\{\left[\mathrm{Cd}\left(\operatorname{tr}_{2} \mathrm{ad}\right)\left(\mathrm{NO}_{3}\right)\right]\left(\mathrm{NO}_{3}\right) \cdot \mathrm{H}_{2} \mathrm{O}\right\}_{n}$ required the application of solvothermal conditions, reacting anhydrous cadmium(II) chloride, copper(II) nitrate hemipentahydrate and cadmium(II) nitrate tetrahydrate, respectively, with $\operatorname{tr}_{2}$ ad in the 1:1 molar ratio (methanol, $100{ }^{\circ} \mathrm{C}, 24 \mathrm{~h}$ ). All the compounds were isolated, in reasonable yields (55-70\%), in the form of air- and moisture-stable microcrystalline powders, insoluble in water and in most common organic solvents (see Section 3.2). 


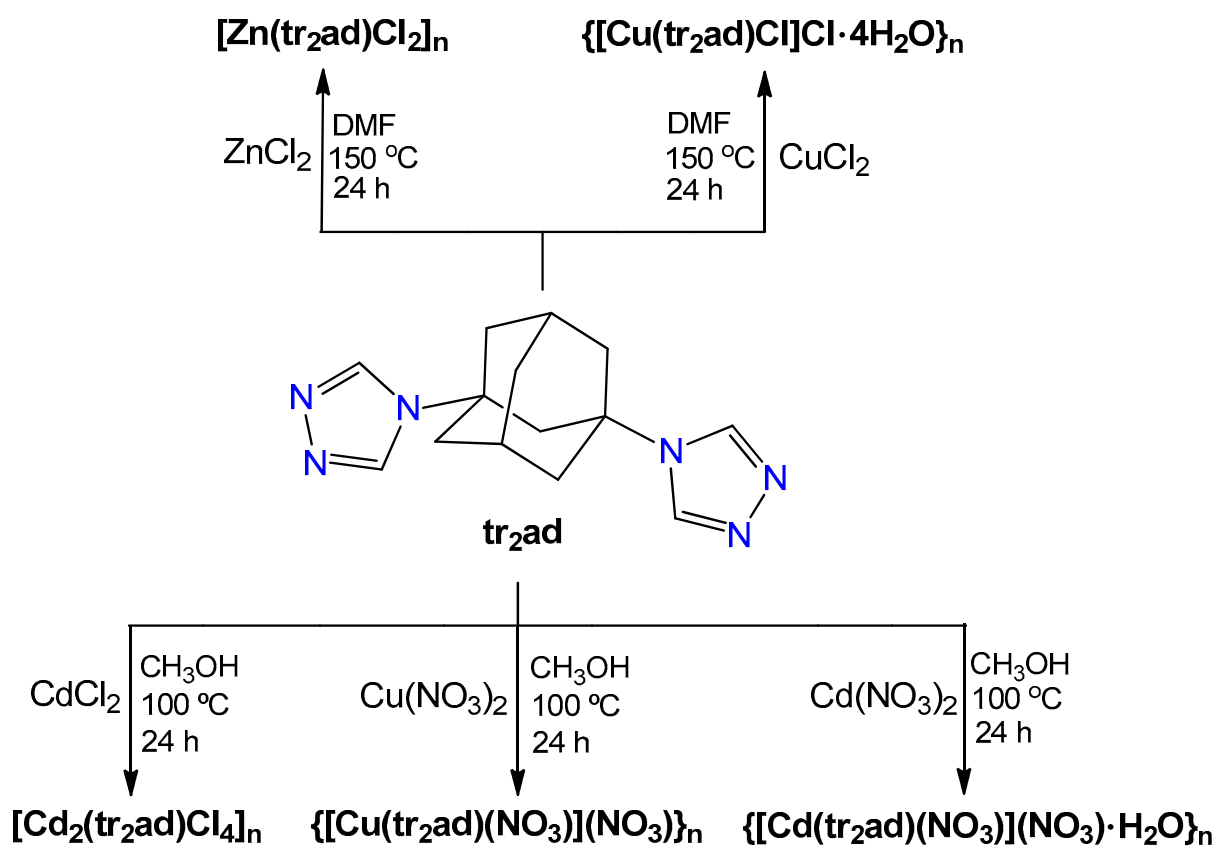

Scheme 2. Synthetic paths for the formation of the $\operatorname{tr}_{2}$ ad-based coordination polymers (CPs) described in this work.

The IR spectrum of the $\operatorname{tr}_{2}$ ad ligand (Figure S1, Supplementary Materials) shows a strong absorption band at $1517 \mathrm{~cm}^{-1}$, which is assigned to the stretching vibration of the triazolyl ring [36]. In the case of the title CPs, this absorption is shifted towards higher wavenumbers $\left(1551-1539 \mathrm{~cm}^{-1}\right)$, as a consequence of the ligand coordination to the metal ions (Figure 1). The medium-intensity broad bands centered around $3400 \mathrm{~cm}^{-1}$ in the IR spectra of compounds $\left\{\left[\mathrm{Cu}\left(\operatorname{tr}_{2} \mathrm{ad}\right) \mathrm{Cl}\right] \mathrm{Cl} \cdot 4 \mathrm{H}_{2} \mathrm{O}\right\}_{n}$ and $\left\{\left[\mathrm{Cd}\left(\operatorname{tr}_{2} \mathrm{ad}\right)\left(\mathrm{NO}_{3}\right)\right]\left(\mathrm{NO}_{3}\right) \cdot \mathrm{H}_{2} \mathrm{O}\right\}_{n}$ (Figure 1), characteristic of the $\mathrm{O}-\mathrm{H}$ stretching vibration, witness the presence of water molecules.
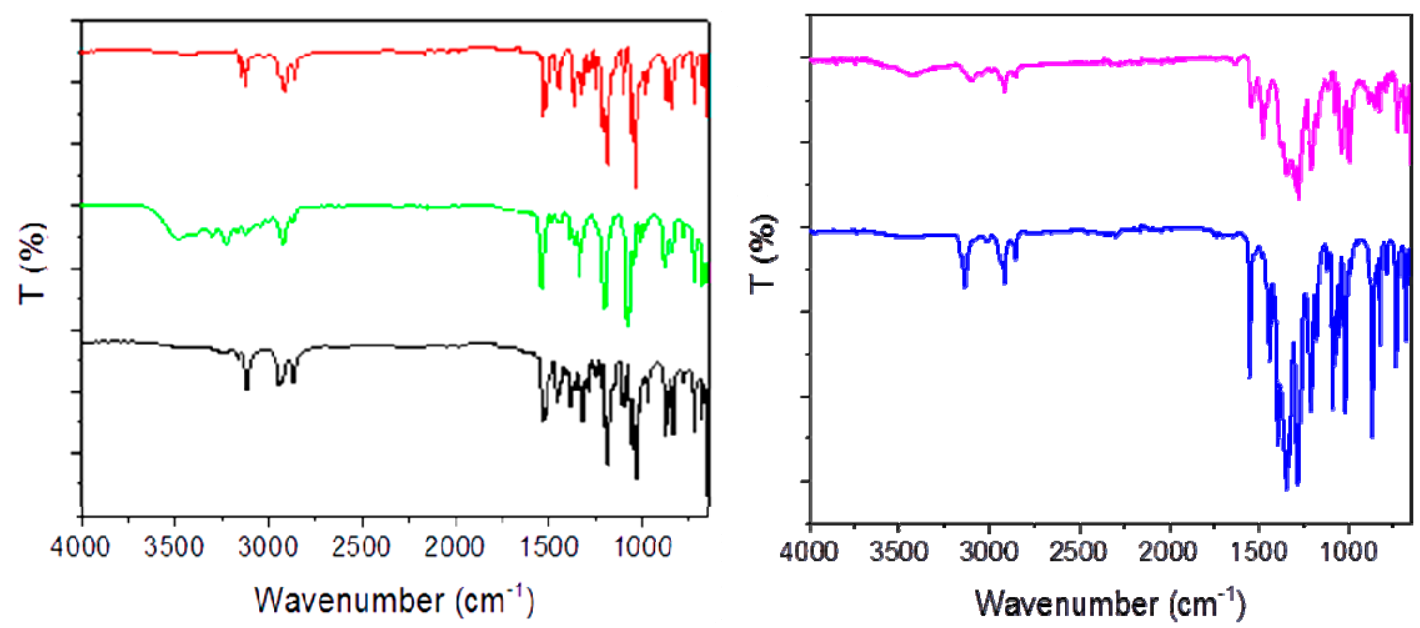

Figure 1. IR spectra of $\left[\mathrm{Zn}\left(\operatorname{tr}_{2} \mathrm{ad}\right) \mathrm{Cl}_{2}\right]_{n}$ (black), $\left\{\left[\mathrm{Cu}\left(\operatorname{tr}_{2} \mathrm{ad}\right) \mathrm{Cl}\right] \mathrm{Cl} \cdot 4 \mathrm{H}_{2} \mathrm{O}\right\}_{n}$ (green), $\left[\mathrm{Cd}_{2}\left(\operatorname{tr}_{2} \mathrm{ad}\right) \mathrm{Cl}_{4}\right]_{n}$ (red), $\left\{\left[\mathrm{Cu}\left(\operatorname{tr}_{2} \mathrm{ad}\right)\left(\mathrm{NO}_{3}\right)\right]\left(\mathrm{NO}_{3}\right)\right\}_{n}$ (blue) and $\left\{\left[\mathrm{Cd}\left(\operatorname{tr}_{2} \mathrm{ad}\right)\left(\mathrm{NO}_{3}\right)\right]\left(\mathrm{NO}_{3}\right) \cdot \mathrm{H}_{2} \mathrm{O}\right\}_{n}$ (fuchsia).

A deeper analysis of the IR spectra of $\left\{\left[\mathrm{Cu}\left(\operatorname{tr}_{2} \mathrm{ad}\right)\left(\mathrm{NO}_{3}\right)\right]\left(\mathrm{NO}_{3}\right)\right\}_{n}$ and $\left\{\left[\mathrm{Cd}\left(\operatorname{tr}_{2} \mathrm{ad}\right)\left(\mathrm{NO}_{3}\right)\right]\left(\mathrm{NO}_{3}\right) \cdot \mathrm{H}_{2} \mathrm{O}_{n}\right.$ (Figure 1) allows to differentiate among the uncoordinated and coordinated forms of the nitrate anion. Indeed, the strong bands located at 1439 and $1282 \mathrm{~cm}^{-1}$ for $\left\{\left[\mathrm{Cu}\left(\operatorname{tr}_{2} \mathrm{ad}\right)\left(\mathrm{NO}_{3}\right)\right]\left(\mathrm{NO}_{3}\right)\right\}_{n}$, and at 1478 and $1275 \mathrm{~cm}^{-1}$ for $\left\{\left[\mathrm{Cd}\left(\operatorname{tr}_{2} \mathrm{ad}\right)\left(\mathrm{NO}_{3}\right)\right]\left(\mathrm{NO}_{3}\right) \cdot \mathrm{H}_{2} \mathrm{O}\right\}_{n}$, assigned to the asymmetric and symmetric stretching vibrations of the nitrate group, together with the presence of two very weak bands, at 1755 and 
$1733 \mathrm{~cm}^{-1}$ for $\left\{\left[\mathrm{Cu}\left(\operatorname{tr}_{2} \mathrm{ad}\right)\left(\mathrm{NO}_{3}\right)\right]\left(\mathrm{NO}_{3}\right)\right\}_{n}$ and at 1748 and $1717 \mathrm{~cm}^{-1}$ for $\left\{\left[\mathrm{Cd}\left(\operatorname{tr}_{2} \mathrm{ad}\right)\left(\mathrm{NO}_{3}\right)\right]\left(\mathrm{NO}_{3}\right) \cdot \mathrm{H}_{2} \mathrm{O}\right\}_{n}$, suggest the presence of $\mu_{2}: \eta^{2}$ nitrate anions [37,38]. At variance, the bands observed at 1394 and $1346 \mathrm{~cm}^{-1}$ for $\left\{\left[\mathrm{Cu}\left(\operatorname{tr}_{2} \mathrm{ad}\right)\left(\mathrm{NO}_{3}\right)\right]\left(\mathrm{NO}_{3}\right)\right\}_{n}$ and at 1374 and $1339 \mathrm{~cm}^{-1}$ for $\left\{\left[\mathrm{Cd}\left(\operatorname{tr}_{2} \mathrm{ad}\right)\left(\mathrm{NO}_{3}\right)\right]\left(\mathrm{NO}_{3}\right) \cdot \mathrm{H}_{2} \mathrm{O}\right\}_{n}$, together with the band centered at $1073 \mathrm{~cm}^{-1}$ in $\left\{\left[\mathrm{Cu}\left(\operatorname{tr}_{2} \mathrm{ad}\right)\left(\mathrm{NO}_{3}\right)\right]\left(\mathrm{NO}_{3}\right)\right\}_{n}$ and at $1076 \mathrm{~cm}^{-1}$ in $\left\{\left[\mathrm{Cd}\left(\operatorname{tr}_{2} \mathrm{ad}\right)\left(\mathrm{NO}_{3}\right)\right]\left(\mathrm{NO}_{3}\right) \cdot \mathrm{H}_{2} \mathrm{O}\right\}_{n}$, can be ascribed to the asymmetric and symmetric stretching modes of uncoordinated nitrate anions [39].

\subsection{Thermal Behaviour}

Thermogravimetric analyses (TGAs) were performed on the five compounds from $30^{\circ} \mathrm{C}$ to $700{ }^{\circ} \mathrm{C}$ under a flow of nitrogen. The resulting TGA curves are gathered in Figure 2. Compound $\left[\mathrm{Zn}\left(\operatorname{tr}_{2} \mathrm{ad}\right) \mathrm{Cl}_{2}\right]_{n}$ is stable up to $350{ }^{\circ} \mathrm{C}$, temperature at which a slow decomposition begins. In the temperature range $30-120{ }^{\circ} \mathrm{C},\left\{\left[\mathrm{Cu}\left(\operatorname{tr}_{2} \mathrm{ad}\right) \mathrm{Cl}\right] \mathrm{Cl} \cdot 4 \mathrm{H}_{2} \mathrm{O}\right\}_{n}$ undergoes a weight loss of ca. $15 \%$, which reasonably corresponds to the evolution of four water molecules per formula unit (calculated weight loss 15.1\%).

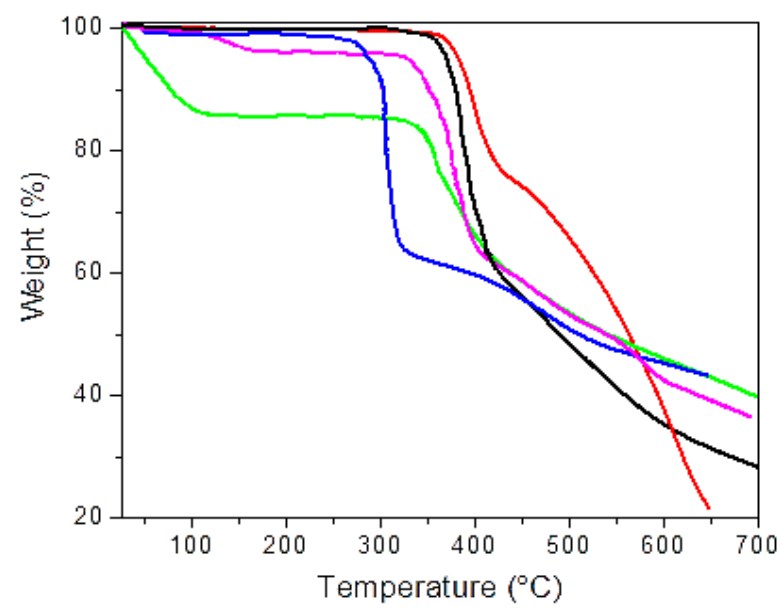

Figure 2. Thermogravimetric analysis (TGA) traces of $\left[\mathrm{Zn}\left(\operatorname{tr}_{2} \mathrm{ad}\right) \mathrm{Cl}_{2}\right]_{n}$ (black), $\left\{\left[\mathrm{Cu}\left(\operatorname{tr}_{2} \mathrm{ad}\right) \mathrm{Cl}\right]\right.$ $\left.\mathrm{Cl} \cdot 4 \mathrm{H}_{2} \mathrm{O}\right\}_{n}$ (green), $\left[\mathrm{Cd}_{2}\left(\operatorname{tr}_{2} \mathrm{ad}\right) \mathrm{Cl}_{4}\right]_{n}$ (red), $\left\{\left[\mathrm{Cu}\left(\operatorname{tr}_{2} \mathrm{ad}\right)\left(\mathrm{NO}_{3}\right)\right]\left(\mathrm{NO}_{3}\right)\right\}_{n}$ (blue) and $\left\{\left[\mathrm{Cd}\left(\operatorname{tr}_{2} \mathrm{ad}\right)\left(\mathrm{NO}_{3}\right)\right]\right.$ $\left.\left(\mathrm{NO}_{3}\right) \cdot \mathrm{H}_{2} \mathrm{O}\right\}_{n}$ (fuchsia).

After solvent loss, no further weight loss is observed up to the decomposition onset at $325^{\circ} \mathrm{C}$. Upon heating, compound $\left\{\left[\mathrm{Cu}\left(\operatorname{tr}_{2} \mathrm{ad}\right)\left(\mathrm{NO}_{3}\right)\right]\left(\mathrm{NO}_{3}\right)\right\}_{n}$ does not undergo any weight loss up to $250^{\circ} \mathrm{C}$, the temperature at which decomposition starts. To the best of our knowledge, the only known 2-D coordination polymers containing the $\operatorname{tr}_{2}$ ad ligand of which the thermal behavior have been studied are $\left[\mathrm{Cu}_{2} \mathrm{II}_{2}\left(\operatorname{tr}_{2} \mathrm{ad}\right)_{4}\right]\left(\mathrm{Mo}_{8} \mathrm{O}_{26}\right),\left[\mathrm{Cu}_{4}{ }_{4}\left(\mu_{4}-\mathrm{O}\right)\left(\operatorname{tr}_{2} \mathrm{ad}\right)_{2}\left(\mathrm{MoO}_{4}\right)_{3}\right] \cdot 7 \cdot 5 \mathrm{H}_{2} \mathrm{O}$ [40] and $\left[\mathrm{Cu}_{3}\left(\operatorname{tr}_{2} \mathrm{ad}\right)_{4}\left(\mathrm{H}_{2} \mathrm{O}\right)_{4}\right]\left(\mathrm{SiF}_{6}\right)_{3} \cdot 16 \mathrm{H}_{2} \mathrm{O}[41]$, which decompose at $310{ }^{\circ} \mathrm{C}, 240{ }^{\circ} \mathrm{C}$ and $190{ }^{\circ} \mathrm{C}$, respectively. Compound $\left[\mathrm{Cd}_{2}\left(\operatorname{tr}_{2} \mathrm{ad}\right) \mathrm{Cl}_{4}\right]_{n}$ displays the highest thermal robustness, peaking up to $365^{\circ} \mathrm{C}$. Until this temperature, no weight loss is observed. Finally, compound $\left\{\left[\mathrm{Cd}\left(\operatorname{tr}_{2} \mathrm{ad}\right)\left(\mathrm{NO}_{3}\right)\right]\left(\mathrm{NO}_{3}\right) \cdot \mathrm{H}_{2} \mathrm{O}\right\}_{n}$ undergoes a weight loss of ca. $3.5 \%$ in the range $30-150{ }^{\circ} \mathrm{C}$, which reasonably corresponds to the release of one water molecule per formula unit (calculated weight loss $3.4 \%$ ). After this event, no further weight losses are observed up to the decomposition onset at $330^{\circ} \mathrm{C}$. To the best of our knowledge, in no case the thermal behavior of the known $\mathrm{Cd}^{\mathrm{II}}$ 2-D coordination polymers containing the $\operatorname{tr}_{2}$ ad ligand has been investigated, so that a comparison cannot be carried out. For the title compounds, at the end of the heating process, black residues, possibly containing carbonaceous species, have been recovered.

\subsection{Crystal and Molecular Structures}

$\operatorname{Tr}_{2}$ ad crystallizes in the monoclinic space group $P 2_{1} / n$. The asymmetric unit contains one $\operatorname{tr}_{2} a d$ molecule in general position. Figure S2a shows the Ortep drawing at $40 \%$ probability level. Due to the 
lack of conventional hydrogen-bond donors, the crystal structure of $\operatorname{tr}_{2}$ ad only features a network of

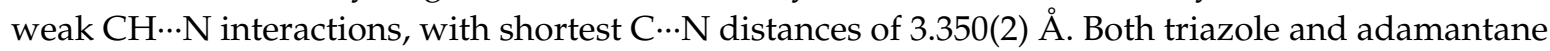
$\mathrm{CH}$ groups act as unconventional hydrogen bond donors, and most of these non-bonding interactions are directional. Two pairs of such $\mathrm{CH} \cdots \mathrm{N}$ interactions, together with a slipped $\pi / \pi$ interaction among adjacent triazole rings (centroid-centroid distance $3.82 \AA$, slippage angle $6.6^{\circ}$ ), concur to the formation of $\operatorname{tr}_{2}$ ad centrosymmetric dimers (Figure $3 a$ ). Such self-association is reminiscent of the pairing of 1,3,5-triphenyladamantane molecules prompted by weak $\mathrm{CH} \cdots \pi$ interactions [42].
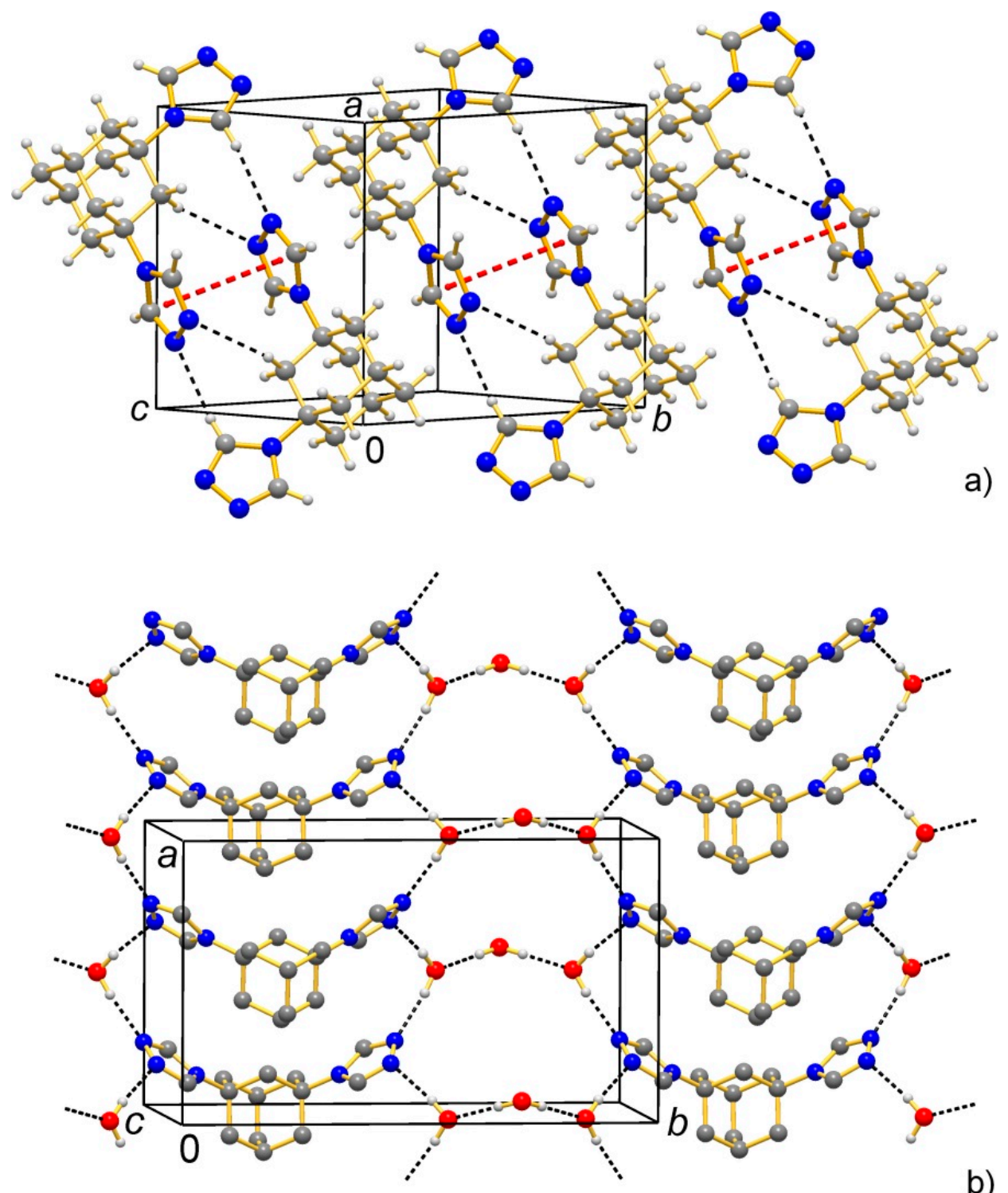

Figure 3. Representation of portion of the crystal structure of (a) $\operatorname{tr}_{2} \mathrm{ad}$ and $(\mathbf{b}) \operatorname{tr}_{2} \mathrm{ad} \cdot 3 \mathrm{H}_{2} \mathrm{O}$, showing the principal supramolecular motifs created by non-bonding interactions involving the triazole nitrogen atoms as acceptors: (a) multiple $\mathrm{CH} \cdots \mathrm{N}$ interactions (black dashed lines) concur with $\pi / \pi$ stacking interactions (red dashed lines) to form $\mathrm{tr}_{2}$ ad dimers; (b) $\mathrm{OH} \cdots \mathrm{N}$ and $\mathrm{OH} \cdots \mathrm{O}$ hydrogen bonds (black dashed lines) support the formation of 2-D supramolecular layers. Atoms colour code: $\mathrm{C}$, grey; $\mathrm{H}$, light grey; $\mathrm{N}$, blue; $\mathrm{O}$, red.

The hydrate ligand $\operatorname{tr}_{2} \mathrm{ad} \cdot 3 \mathrm{H}_{2} \mathrm{O}$ crystallizes in the orthorhombic space group Pnma. The asymmetric unit contains half of a $\operatorname{tr}_{2}$ ad molecule and half of $\mathrm{H}_{2} \mathrm{O}$ molecule, both situated across a mirror plane (Wyckoff letter $c$ ), and one water molecule in general position. Figure S2b shows the Ortep drawing at $30 \%$ probability level. The primary intermolecular interactions in the crystal structure are conventional 
$\mathrm{OH} \cdots \mathrm{N}$ hydrogen bonds $(\mathrm{O} \cdots \mathrm{N}=2.896(3), 2.932(3) \AA)$ involving all the triazole nitrogen atoms as acceptors. These interactions assemble the $\operatorname{tr}_{2}$ ad and water molecules (in a 1:2 ratio) into 1-D strips along the crystallographic $a$-axis (Figure $3 \mathrm{~b}$ ). Additional water molecules establish bridges between the strips through pairs of symmetry-equivalent $\mathrm{OH} \cdots \mathrm{O}$ bonds $(\mathrm{O} \cdots \mathrm{O}=2.764(2) \AA)$ (Figure 3b). The 2-D hydrogen-bond connectivity comprises water trimers $\mathrm{H}_{2} \mathrm{O} \cdots \mathrm{H}-\mathrm{O}-\mathrm{H} \cdots \mathrm{OH}_{2}$ linked to four triazole-N sites. Overall, the crystal structures of $\operatorname{tr}_{2}$ ad and $\operatorname{tr}_{2}$ ad $33 \mathrm{H}_{2} \mathrm{O}$ reveal the potentiality of triazole- $N^{1}, N^{2}$ atoms as efficient hydrogen-bond acceptors.

Compound $\left[\mathrm{Zn}\left(\operatorname{tr}_{2} \mathrm{ad}\right) \mathrm{Cl}_{2}\right]_{n}$ crystallizes in the orthorhombic space group $P 2{ }_{1} 2_{1} 2_{1}$. The asymmetric unit contains one $\mathrm{Zn}^{\mathrm{II}}$ ion, one $\mathrm{tr}_{2}$ ad ligand and two chloride anions, all in general positions. The metal centre shows a $\mathrm{ZnCl}_{2} \mathrm{~N}_{2}$ tetrahedral stereochemistry (Figure 4a; the Figure caption collects the values of the bond distances and angles at the metal ion), defined by two chloride anions and the nitrogen atoms of the triazole rings of two $\operatorname{tr}_{2}$ ad ligands. The ligands are exo-bidentate $\left(\mu_{2}-\kappa N^{1}: \kappa N^{1^{\prime}}\right)$ and bridge neighbouring $\mathrm{Zn}^{\mathrm{II}}$ ions along 1-D polymeric chains (Figure $4 \mathrm{~b}$ ) of pitch 11.120(4) $\AA$ parallel to the [001] crystallographic direction (this occurrence rationalizing the preferred orientation pole; see Section 3.3). The chains pack in the $a b$ plane defining a rectangular motif (Figure 4c). Non-bonding interactions of the kind $\mathrm{C}-\mathrm{H} \cdots \mathrm{N}(\mathrm{C} \cdots \mathrm{N} 3.2 \AA)$ and $\mathrm{C}-\mathrm{H} \cdots \mathrm{Cl}$ involving both chloride anions $(\mathrm{C} \cdots \mathrm{Cl}$ 3.5-3.7 $\AA$ ) are at work within the chains and between nearby chains, respectively. No empty volume is present [43].

a)

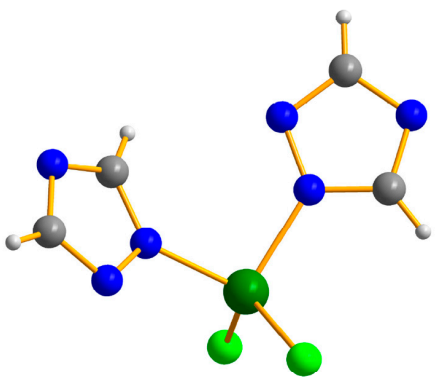

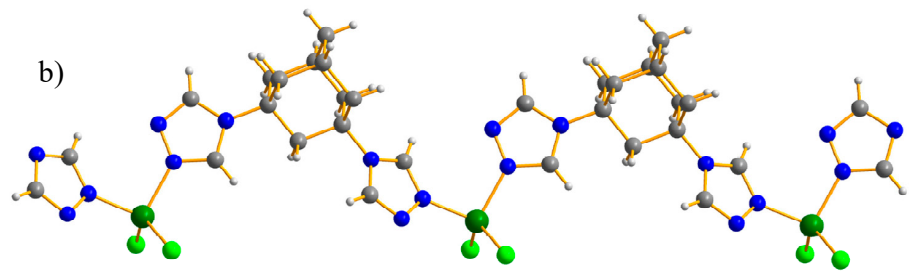

c)
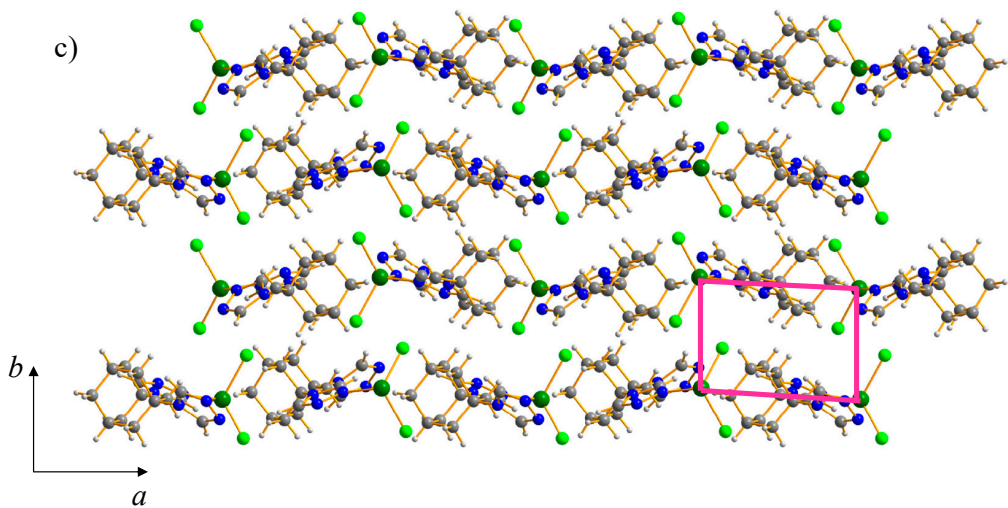

Figure 4. Representation of the crystal structure of $\left[\mathrm{Zn}\left(\mathrm{tr}_{2} \mathrm{ad}\right) \mathrm{Cl}_{2}\right]_{n}$ : (a) the coordination sphere of the $\mathrm{Zn}{ }^{\mathrm{II}}$ ions; (b) portion of the 1-D polymeric motif running along the [001] crystallographic direction; (c) portion of the packing, viewed along the [001] crystallographic direction. Horizontal axis, $a$; Vertical axis, $b$. Highlighted in fuchsia the rectangular packing of the 1-D chains. Atoms colour code: $\mathrm{C}$, grey; H, light grey; $\mathrm{Cl}$, light green; N, blue; Zn, green. Main bond distances $(\AA)$ and angles $\left({ }^{\circ}\right)$ at the metal ions: $\mathrm{Zn}-\mathrm{Cl} 2.153(7), 2.316(7) ; \mathrm{Zn}-\mathrm{N}$ 1.944(9), 2.01(1); shortest intra-chain Zn $\cdots \mathrm{Zn} 11.120(3)$; N-Zn-N 99.5(5); Cl-Zn-Cl 117.7(2); Cl-Zn-N 107.0(6), 107.1(5), 110.0(5), 113.7(7).

Compound $\left\{\left[\mathrm{Cu}\left(\operatorname{tr}_{2} \mathrm{ad}\right) \mathrm{Cl}\right] \mathrm{Cl} \cdot 4 \mathrm{H}_{2} \mathrm{O}\right\}_{n}$ crystallizes in the monoclinic space group $P 2_{1} / m$. The asymmetric unit is composed by half of a metal centre (on an inversion centre, Wyckoff letter $b$ ), half of a $\operatorname{tr}_{2}$ ad ligand, two halves of a chloride anion and two halves of a water molecule (all on mirror planes, Wyckoff letter $e$ ), as well as one water molecule (in general position). The $\mathrm{Cu}^{\mathrm{II}}$ ions are hexa-coordinated in trans- $\mathrm{CuCl}_{2} \mathrm{~N}_{4}$ octahedral geometry defined by the nitrogen atoms of four $\operatorname{tr}_{2}$ ad ligands and one 
of the two independent chloride anions (Figure 5a; the main bond distances and angles at the metal ions are reported in the Figure caption). $\mu$-coordination by triazole rings and coordinated chloride anions brings about the formation of 1-D helices of metal ions (Figure 5b) with pitch 3.5863(2) $\AA$ (half of the $b$-axis) running along the crystallographic direction [010]. The $\operatorname{tr}_{2}$ ad ligands, which are overall exo-tetradentate $\left(\mu_{4}-\kappa N^{1}: \kappa N^{2}: \kappa N^{1^{\prime}}: \kappa N^{2^{\prime}}\right)$, connect the helices along the crystallographic direction [001], bringing about the formation of 2-D double-layers parallel to the $b c$ crystallographic plane (Figure $5 c$ ). The layers pack, staggered, along the $a$-axis. The second independent chloride anion and one of the four independent water molecules occupy the rhombic cavities formed by the ligands within the double-layers (Figure 5c) and are involved in a $\mathrm{HO}-\mathrm{H} \cdots \mathrm{Cl}$ non-bonding interaction $(\mathrm{O} \cdots \mathrm{Cl} 2.58(3) \AA$; Figure S7a). The other three water molecules are located in the inter-layer space and, by means of

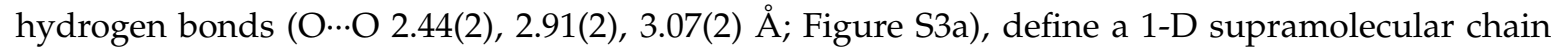
running parallel to the $b$-axis. Finally, the double layers are reinforced by $\mathrm{C}-\mathrm{H} \cdots \mathrm{Cl}$ interactions $(\mathrm{C} \cdots \mathrm{Cl}$ 3.3-3.4 A; Figure S3b). No empty volume is envisaged [43].

a)

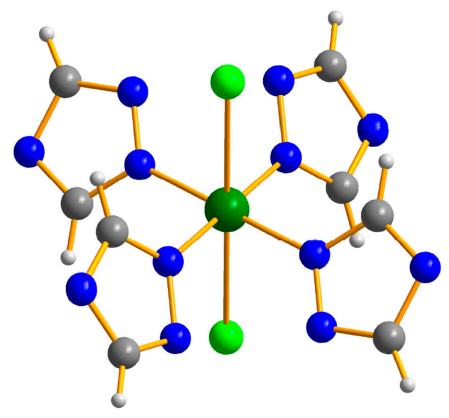

b)

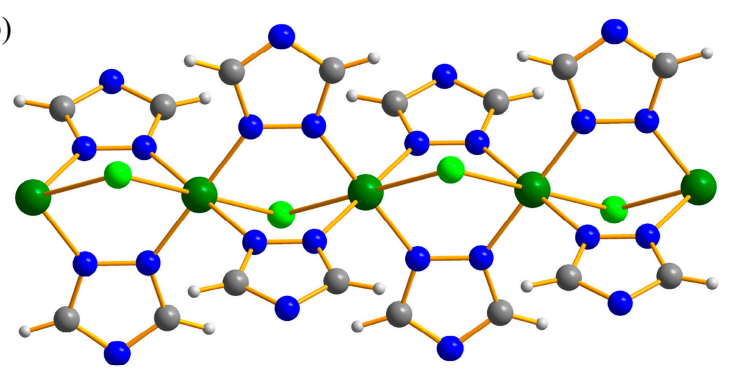

c)

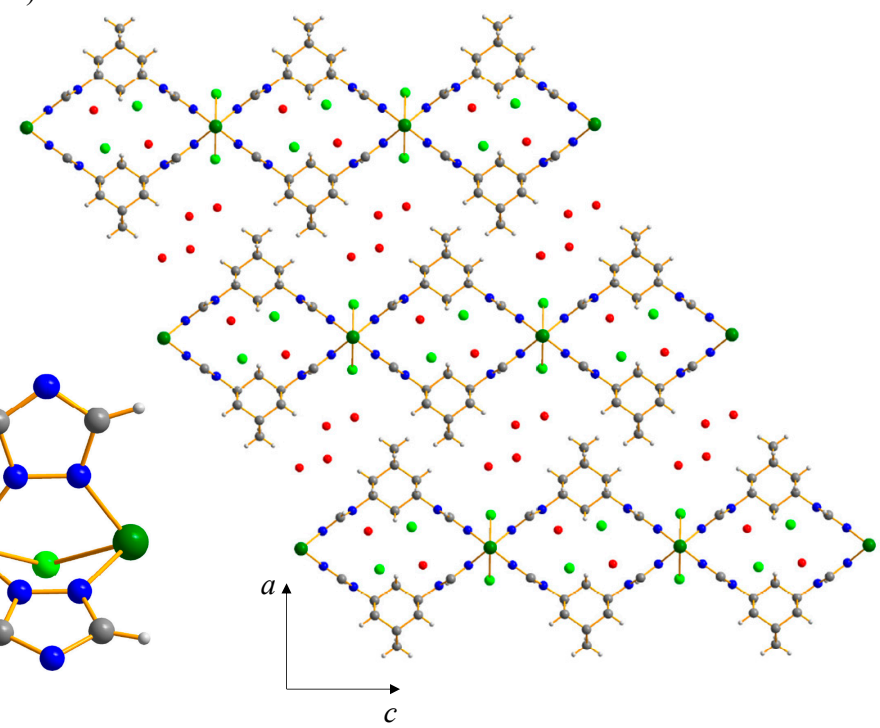

Figure 5. Representation of the crystal structure of $\left\{\left[\mathrm{Cu}\left(\operatorname{tr}_{2} \mathrm{ad}\right) \mathrm{Cl}\right] \mathrm{Cl} \cdot 4 \mathrm{H}_{2} \mathrm{O}\right\}_{n}$ : (a) the coordination sphere of the metal ions; (b) portion of the 1-D helix; (c) portion of the packing, viewed along the [010] crystallographic direction. Horizontal axis, $c$; vertical axis, $a$. For the non-bonding interactions quoted in the text the reader is addressed to Figure S3. Atoms colour code: $\mathrm{C}$, grey; $\mathrm{H}$, light grey; $\mathrm{Cl}$, light green; $\mathrm{Cu}$, green; $\mathrm{N}$, blue; $\mathrm{O}$, red. Main bond distances $(\AA)$ and angles $\left(^{\circ}\right)$ at the metal ions: $\mathrm{Cu}-\mathrm{Cl}$ 2.632(7); $\mathrm{Cu}-\mathrm{N} 1.969(4), 2.009(6)$; shortest $\mathrm{Cu} \cdots \mathrm{Cu}$ intra-chain 3.5863(2); shortest $\mathrm{Cu} \cdots \mathrm{Cu}$ inter-chain 10.9798(7); N-Cu-N 80.4(3), 99.6(3), 180; Cl-Cu-Cl 180; Cl-Cu-N 88.1(3), 89.7(3), 90.3(3), 91.9(3).

Compound $\left[\mathrm{Cd}_{2}\left(\operatorname{tr}_{2} \mathrm{ad}\right) \mathrm{Cl}_{4}\right]_{n}$ crystallizes in the triclinic space group $P-1$. The asymmetric unit equals the formula unit, i.e., it contains two cadmium(II) ions, four chloride anions and one $\operatorname{tr}_{2} a d$ ligand, all in general positions. Both independent metal centres are hexa-coordinated and show an octahedral stereochemistry, though of different kind, namely: cis- $\mathrm{CdN}_{2} \mathrm{Cl}_{4}$ and $\mathrm{CdNCl}_{5}$ (Figure 6a; the main bond distances and angles at the metal ions are reported in the Figure caption). Three of the four chloride anions bridge adjacent metal centres, while the fourth one behaves as a terminal ligand. The $\operatorname{tr}_{2}$ ad spacer is exo-tridentate $\left(\mu_{3}-\kappa N^{1}: \kappa N^{2}: \kappa N^{1^{\prime}}\right)$. The reciprocal disposition of cations and anions brings about the formation of 1-D polymeric strands (Figure 6b) running along the [100] crystallographic direction. The $\operatorname{tr}_{2}$ ad linkers bridge nearby strands leading to the formation of 2-D double-layers parallel to the (01-1) plane and packing, staggered, along the [011] direction (Figure 6c). The reciprocal disposition of the spacers within a layer brings about the formation of intra-layer rhombic cavities, in which the terminal chloride anions are directed (Figure 6c). This structural motif is 
analogous to that found in $\left\{\left[\mathrm{Cu}\left(\operatorname{tr}_{2} \mathrm{ad}\right) \mathrm{Cl}\right] \mathrm{Cl} \cdot 4 \mathrm{H}_{2} \mathrm{O}\right\}_{n}$ (see above). Weak intra- and inter-layer $\mathrm{C}-\mathrm{H} \cdots \mathrm{Cl}$ interactions ( $\mathrm{C} \cdots \mathrm{Cl}$ 3.3-3.7 $\AA$ ) are present. No empty volume is observed [43].

a)

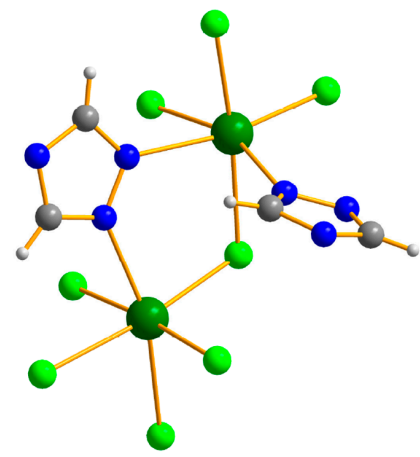

b)

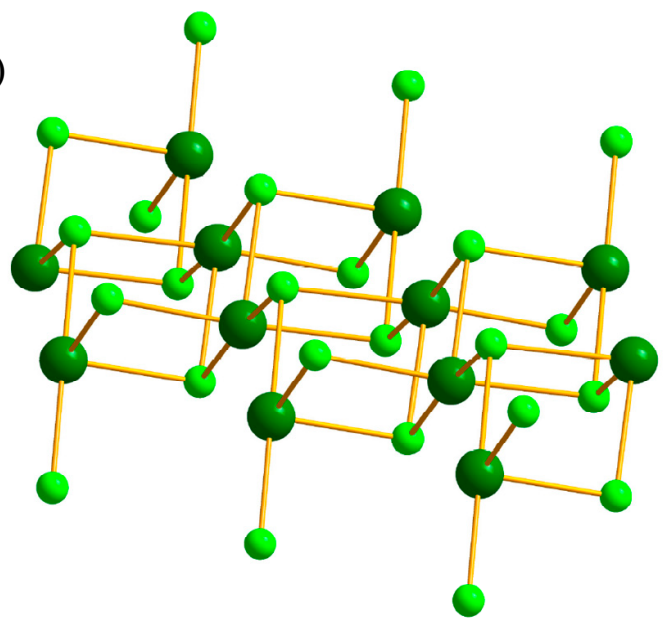

c)

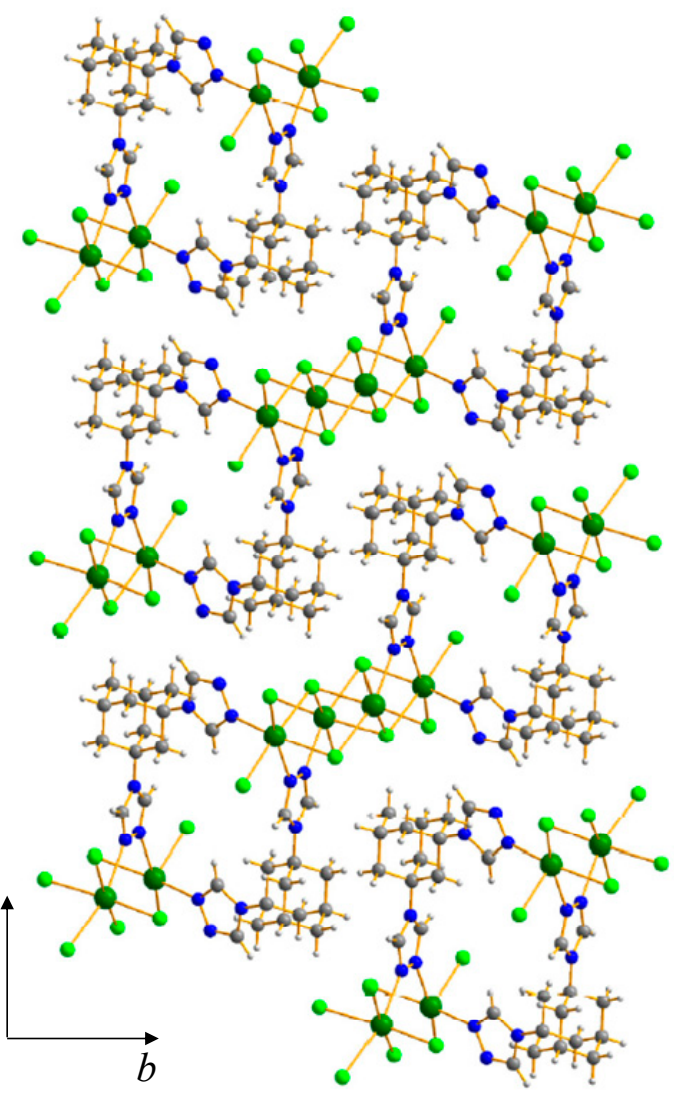

Figure 6. Representation of the crystal structure of $\left[\mathrm{Cd}_{2}\left(\operatorname{tr}_{2} \mathrm{ad}\right) \mathrm{Cl}_{4}\right]_{n}$ : (a) the coordination sphere of the metal ions; (b) portion of the 1-D polymeric strands; (c) portion of the packing, viewed along the [100] crystallographic direction. Horizontal axis, $b$; vertical axis, $c$. Atoms colour code: $\mathrm{C}$, grey; $\mathrm{H}$, light grey; $\mathrm{Cl}$, light green; $\mathrm{Cd}$, green; $\mathrm{N}$, blue. Main bond distances $(\AA)$ and angles $\left(^{\circ}\right)$ at the metal ions: $\mathrm{Cd} 1-\mathrm{Cl} 2.59(2), 2.62(2), 2.75(2), 2.82(2), 2.87(2) ; \mathrm{Cd} 1-\mathrm{N}$ 2.42(3); $\mathrm{Cd} 2-\mathrm{Cl}$ 2.58(2), 2.59(1), 2.62(2), 2.78(2); $\mathrm{Cd} 2-\mathrm{N}$ 2.32(2), 2.32(3); shortest intra-strand $\mathrm{Cd} \cdots \mathrm{Cd} 3.842(8)-4.241(8)$; shortest inter-strand $\mathrm{Cd} \cdots \mathrm{Cd}$ 7.526(7) Cl-Cd1-N 84(1)-165.0(1); Cl-Cd1-Cl 82.5(5)-174.2(5); Cl-Cd2-N 77(1)-165(1); Cl-Cd2-Cl 85.6(5)-173.5(6); N-Cd2-N 92.2(8).

Compound $\left\{\left[\mathrm{Cu}\left(\operatorname{tr}_{2} \mathrm{ad}\right)\left(\mathrm{NO}_{3}\right)\right]\left(\mathrm{NO}_{3}\right)\right\}_{n}$ crystallizes in the orthorhombic space group Pnma. The asymmetric unit is composed by one $\mathrm{Cu}^{\mathrm{II}}$ ion, two halves of nitrate anions and half of a $\operatorname{tr}_{2}$ ad spacer, all lying on mirror planes (Wyckoff letter $h$ ). The metal centre is hexa-coordinated in trans- $-\mathrm{CuN}_{4} \mathrm{O}_{2}$ stereochemistry (Figure 7a; the main bond distances and angles at the metal ions are reported in the Figure caption), defined by four $\operatorname{tr}_{2}$ ad linkers and one of the two independent nitrate anions. The latter bridges $\left(\mu_{2}-\mathrm{k} O^{1}: \mathrm{k} O^{2}\right)$ nearby metal centres 3.54(2) $\AA$ apart, while the other nitrate anion is not coordinated. The $\operatorname{tr}_{2}$ ad ligand is exo-tetradentate $\left(\mu_{4}-\kappa N^{1}: \kappa N^{2}: \kappa N^{1^{\prime}}: \kappa N^{2^{\prime}}\right)$. $\mu_{2}$-bridging of the nitrate anions and triazole rings brings about the formation of 1-D chains running along the [100] direction (Figure $7 b$ ). 
a)
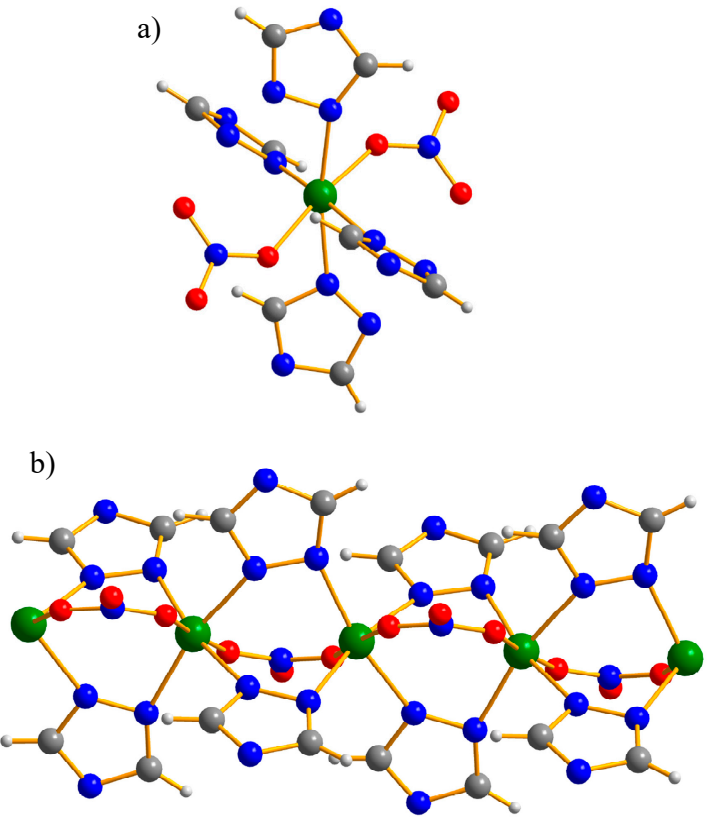

c)

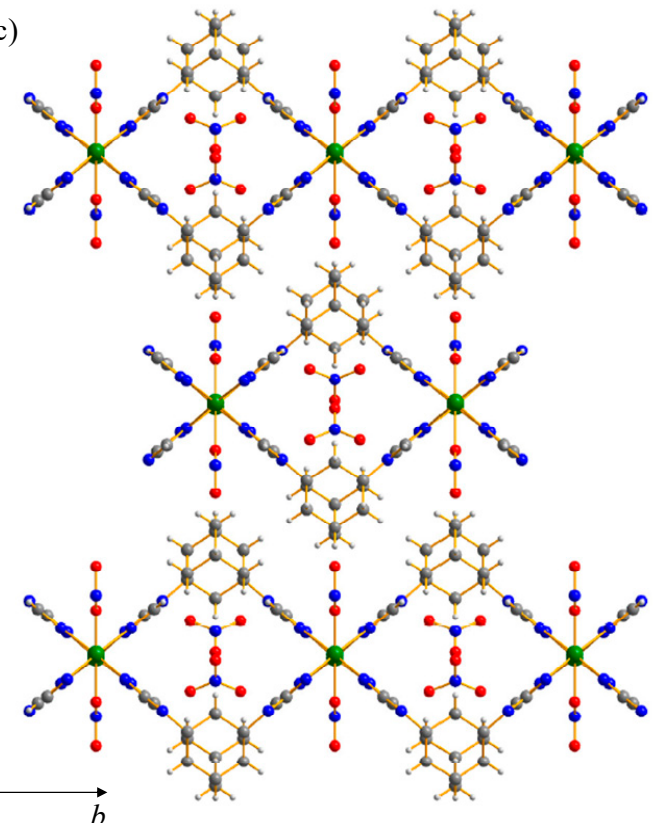

Figure 7. Representation of the crystal structure of $\left\{\left[\mathrm{Cu}\left(\mathrm{tr}_{2} \mathrm{ad}\right)\left(\mathrm{NO}_{3}\right)\right]\left(\mathrm{NO}_{3}\right)\right\}_{n}$ : (a) the coordination sphere of the metal ions; (b) portion of the 1-D polymeric chain; (c) portion of the packing, viewed along the [100] crystallographic direction. Horizontal axis, $b$; vertical axis, $c$. Atoms colour code: $C$, grey; $\mathrm{H}$, light grey; $\mathrm{Cu}$, green; $\mathrm{N}$, blue; $\mathrm{O}$, red. Main bond distances $(\AA)$ and angles $\left({ }^{\circ}\right)$ at the metal ions: $\mathrm{Cu}-\mathrm{N}$ 2.03(1), 2.148(9); $\mathrm{Cu}-\mathrm{O} 2.09(2), 2.26(2)$; intra-chain shortest $\mathrm{Cu} \cdots \mathrm{Cu}$ 3.54(2); inter-chain shortest Cu‥Cu 10.7226(7); N-Cu-N 76.4(6), 97.01(3), 173.5(5); O-Cu-O 180(1); O-Cu-N 68.9(5), 70.3(6), 109.8(6), 111.0(6).

Nearby chains are connected along [010] by the $\operatorname{tr}_{2}$ ad spacers within 2-D polymeric double-layers parallel to the (001) plane and packing, staggered, along the [001] direction (Figure 7c; this occurrence explains the preferred orientation pole-see Section 3.3). The reciprocal disposition of the $\operatorname{tr}_{2} \mathrm{ad}$ linkers within a layer brings about the formation of intra-layer rhombic cavities, in which the not coordinated nitrate anions are located (Figure $7 \mathrm{c}$ ) and involved in $\mathrm{C}-\mathrm{H} \cdots \mathrm{O}$ non-bonding interactions (C...O 2.6-3.2 $\AA$ ). The structural motif is analogous to that found in the $\mathrm{Cu}^{\mathrm{II}}$ and $\mathrm{Cd}^{\mathrm{II}}$ compounds described above. No empty volume is observed [43].

Compound $\left\{\left[\mathrm{Cd}\left(\operatorname{tr}_{2} \mathrm{ad}\right)\left(\mathrm{NO}_{3}\right)\right]\left(\mathrm{NO}_{3}\right) \cdot \mathrm{H}_{2} \mathrm{O}\right\}_{n}$ crystallizes in the monoclinic space group $\mathrm{C} 2 / c$. The asymmetric unit contains two halves of $\mathrm{Cd}^{\mathrm{II}}$ ions (one on an inversion centre, Wyckoff position $b$, the other one on a two-fold axis, Wyckoff position $e$ ), two nitrate anions, one $\operatorname{tr}_{2}$ ad ligand and one water molecule-all in general positions. The metal centres are hexa-coordinated in trans-CdN $\mathrm{O}_{2}$ octahedral stereochemistry defined by four ligands and two nitrate anions (Figure 8a; the main bond distances and angles at the metal ions are reported in the Figure caption). One of the two independent nitrate anions bridge $\left(\mu_{2}-\kappa O^{1}: \kappa O^{2}\right)$ neighbouring metal centres, while the other one is not coordinated. The $\operatorname{tr}_{2}$ ad spacer is exo-tetradentate $\left(\mu_{4}-\kappa N^{1}: \kappa N^{2}: \kappa N^{1^{\prime}}: \kappa N^{2^{\prime}}\right)$. $\mu_{2}$-Coordination of the nitrate anions and triazole rings is responsible for the formation of 1-D chains parallel to the [001] crystallographic direction (Figure 8b). Adjacent chains are bridged along the [010] direction to yield 2-D double-layers parallel to the $b c$ plane and packing, staggered, along the $a$-axis (Figure $8 \mathrm{c}$; this occurrence explains the preferred orientation pole-see Section 3.3). The reciprocal disposition of the $\operatorname{tr}_{2}$ ad linkers within a layer brings about the formation of intra-layer rhombic cavities, in which the not coordinated nitrate anions are located (Figure 8c). The structural motif is analogous to that found in the $\mathrm{Cu}^{\mathrm{II}}$ and $\mathrm{Cd}^{\mathrm{II}}$ compounds described above. The water molecules are located in the inter-layer space (Figure 8c) and are involved in $\mathrm{C}-\mathrm{H} \cdots \mathrm{O}$ non-bonding interactions (C… 2.9-3.2 $\AA$ ) with adjacent $\operatorname{tr}_{2}$ ad ligands. No empty volume is observed [43]. 

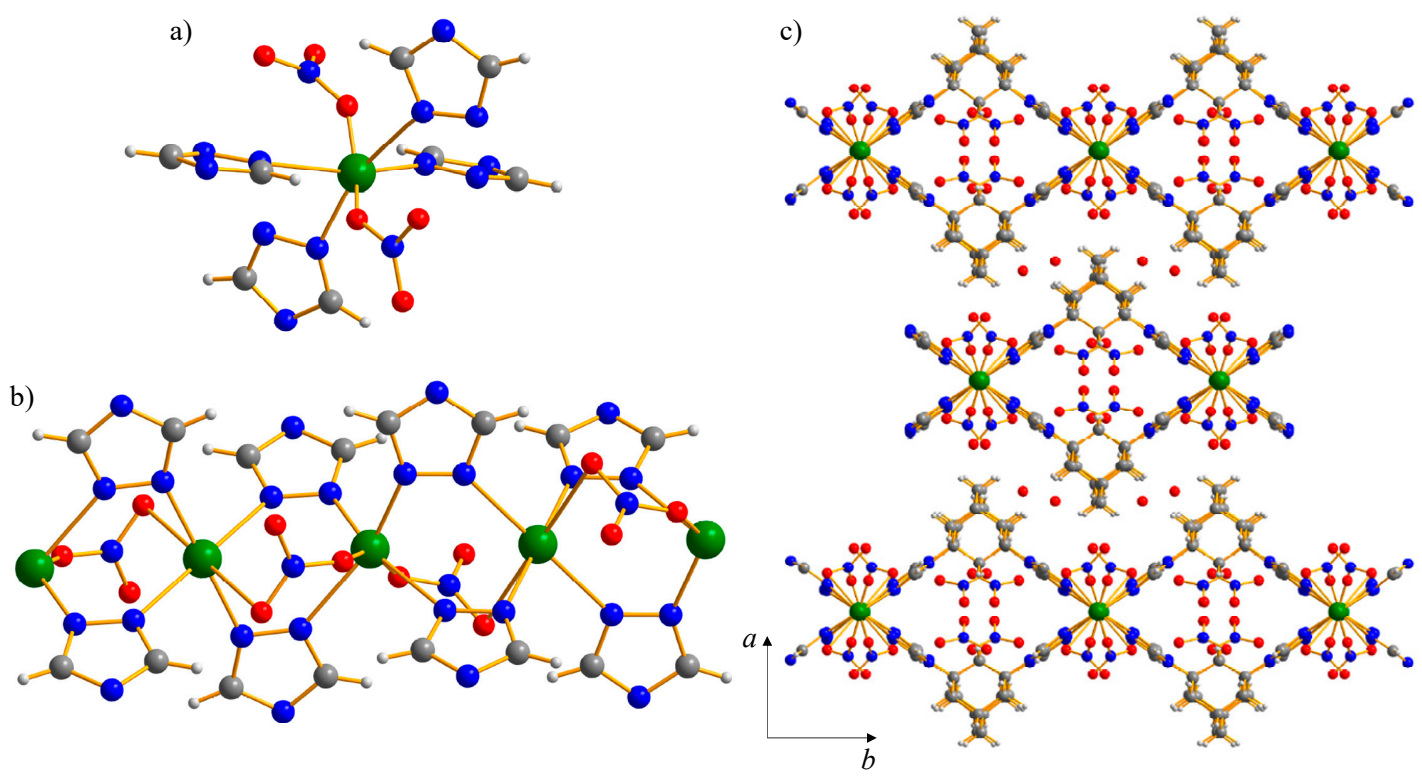

Figure 8. Representation of the crystal structure of $\left\{\left[\mathrm{Cd}\left(\operatorname{tr}_{2} \mathrm{ad}\right)\left(\mathrm{NO}_{3}\right)\right]\left(\mathrm{NO}_{3}\right) \cdot \mathrm{H}_{2} \mathrm{O}\right\}_{n}$ : (a) the coordination sphere of the metal ions; (b) portion of the 1-D polymeric chains; (c) portion of the packing, viewed in perspective along the [001] crystallographic direction. Horizontal axis, $b$; vertical axis, $a$. Atoms colour code: $\mathrm{C}$, grey; $\mathrm{H}$, light grey; $\mathrm{Cu}$, green; $\mathrm{N}$, blue; $\mathrm{O}$, red. Main bond distances $(\AA)$ and angles $\left(^{\circ}\right)$ at the metal ions: Cd1-N 2.24(1), 2.30(1); Cd1-O 1.54(3); Cd2-N 2.17(1), 2.23(1); Cd2-O 2.79(4); intra-chain Cd...Cd 3.8724(3); inter-chain Cd...Cd 11.39(2); N-Cd1-N 80.2(5)-176.3(5); O-Cd1-O 168(3); N-Cd1-O 72(1)-105(1); N-Cd2-N 88.7(6), 91.3(6), 180; O-Cd2-O 180; N-Cd2-O 68(1)-110.1(8).

\subsection{Comparative Structure Analysis}

A search in the Cambridge Structural Database (v 2020.1) for coordination compounds containing the $\operatorname{tr}_{2}$ ad ligand has revealed the existence of 22 coordination polymers. Table 1 collects key structural aspects (coordination sphere and geometry at the metal ion, $\operatorname{tr}_{2}$ ad ligand hapticity, polymer dimensionality) of these compounds. The following observations can be carried out:

1. Among the CPs retrieved in the literature (Table 1), 14 contain $\mathrm{Cu}^{\mathrm{II}}$ or $\mathrm{Cd}^{\mathrm{II}}$, while the others feature $\mathrm{Cu}^{\mathrm{I}}, \mathrm{Ag}^{\mathrm{I}}, \mathrm{Mo}^{\mathrm{II}}$ or $\mathrm{Fe}^{\mathrm{II}}$. Hence, to the best of our knowledge, $\left[\mathrm{Zn}\left(\operatorname{tr}_{2} \mathrm{ad}\right) \mathrm{Cl}_{2}\right]_{n}$ is the first example of $\mathrm{Zn}^{\text {II }}$-based coordination compound containing the $\operatorname{tr}_{2}$ ad ligand.

2. As regards the stereochemistry at the metal ion, apart from $\left[\mathrm{Cd}_{3}\left(\operatorname{tr}_{2} \mathrm{ad}\right)_{2} \mathrm{I}_{6}\right]$, in which one of the two independent $\mathrm{Cd}^{\mathrm{II}}$ ions shows a tetrahedral geometry, in all the known $\mathrm{Cd}^{\mathrm{II}} \mathrm{CPs}$ the metal centre adopts an octahedral geometry, as in $\left[\mathrm{Cd}\left(\operatorname{tr}_{2} \mathrm{ad}\right) \mathrm{Cl}_{4}\right]_{n}$ and $\left\{\left[\mathrm{Cd}\left(\operatorname{tr}_{2} \mathrm{ad}\right)\left(\mathrm{NO}_{3}\right)\right]\left(\mathrm{NO}_{3}\right) \cdot \mathrm{H}_{2} \mathrm{O}\right\}_{n}$. On the other hand, while in $\left\{\left[\mathrm{Cu}\left(\operatorname{tr}_{2} \mathrm{ad}\right) \mathrm{Cl}\right] \mathrm{Cl} \cdot 4 \mathrm{H}_{2} \mathrm{O}\right\}_{n}$ and $\left\{\left[\mathrm{Cu}\left(\operatorname{tr}_{2} \mathrm{ad}\right)\left(\mathrm{NO}_{3}\right)\right]\left(\mathrm{NO}_{3}\right)\right\}_{n}$ the metal ion is in octahedral stereochemistry, in the known $\mathrm{CPs}$ the $\mathrm{Cu}^{\mathrm{II}}$ coordination number varies in the range 4-6, with different coordination geometries associated (Table 1).

3. Upon comparing the values of the $\mathrm{M}-\mathrm{N}$ distances ( $\mathrm{M}=\mathrm{Cu}^{\mathrm{II}}$ or $\mathrm{Cd}{ }^{\mathrm{II}}, \mathrm{N}=\operatorname{tr}_{2}$ ad nitrogen atom), it appears (Figure S4) that the novel materials share distances comparable with those of the literature CPs.

4. Apart from $\left[\mathrm{Zn}\left(\operatorname{tr}_{2} \mathrm{ad}\right) \mathrm{Cl}_{2}\right]_{n}$, all the other compounds studied in this work are 2-D coordination polymers characterized by the same structural motif (see Figures 4-8). At variance, Table 1 shows that in the known compounds the dimensionality ranges from 1-D to 3-D. Interestingly, the structural motif observed in the title $\mathrm{Cu}^{\mathrm{II}}$ and $\mathrm{Cd}^{\mathrm{II}}$ derivatives, with rhombic cavities within 2-D strands, is shown also by COVFIE, COVFOK, KEHDEI, KEMLEV and TUGSIY, containing $\mathrm{Cu}^{\mathrm{II}}$ or $\mathrm{Cd}^{\mathrm{II}}$ ions, and UZAKIQ, containing the $\mathrm{Mo}^{\mathrm{II}}$ ion. 
Table 1. Main structural properties of the known coordination polymers containing the $\operatorname{tr}_{2}$ ad ligand. Abbreviations: $M=$ metal ion; $O C=$ octahedral; $\mathrm{SP}=$ square planar; $\mathrm{SQP}=$ square pyramidal; $\mathrm{TB}=$ trigonal bipyramidal; $\mathrm{TD}=$ tetrahedral; $\mathrm{TP}=$ trigonal planar; $\mathrm{H}_{3} \mathrm{btc}=1,3,5$-benzenetricarboxylic acid; $\mathrm{H}_{4}$ adtc $=1,3,5,7$-adamantane-tetracarboxylic acid; ${ }^{\text {a }} \mathrm{M}-\mathrm{F}$.

\begin{tabular}{|c|c|c|c|c|c|c|c|c|}
\hline CSD Code & Molecular Formula & M Stereochemistry & M Geometry & M-N (Å) & M-X (Å) & $\operatorname{Tr}_{2}$ ad Apticity & Dim. & Ref. \\
\hline COVFIE & {$\left[\mathrm{Cu}_{2}\left(\operatorname{tr}_{2} \mathrm{ad}\right)_{4}\right]\left(\mathrm{Mo}_{8} \mathrm{O}_{26}\right)$} & $\mathrm{CuN}_{5}$ & SP & $1.968-2.247$ & - & $\begin{array}{l}\text { Exo-bidentate } \\
\text { Exo-tridentate }\end{array}$ & 2-D & [40] \\
\hline COVFOK & {$\left[\mathrm{Cu}_{4}\left(\operatorname{tr}_{2} \mathrm{ad}\right)_{2}\left(\mu_{4}-\mathrm{O}\right)\left(\mathrm{MoO}_{4}\right)_{3}\right] \cdot 7 \cdot 5 \mathrm{H}_{2} \mathrm{O}$} & $\begin{array}{l}\mathrm{CuN}_{2} \mathrm{O}_{3} \\
\mathrm{CuN}_{2} \mathrm{O}_{3} \\
\mathrm{CuN}_{2} \mathrm{O}_{3}\end{array}$ & $\begin{array}{l}\text { TB } \\
\text { TB } \\
\text { TB }\end{array}$ & $\begin{array}{c}2.078,2.093 \\
2.005 \\
2.009\end{array}$ & $\begin{array}{l}1.923-2.028 \\
1.937-2.090 \\
1.937-2.067\end{array}$ & Exo-tetradentate $(2 \times)$ & 2-D & [40] \\
\hline COVFUQ & {$\left[\mathrm{Cu}_{2}\left(\operatorname{tr}_{2} \mathrm{ad}\right)_{2}\right]\left(\mathrm{Mo}_{2} \mathrm{O}_{7}\right) \cdot \mathrm{H}_{2} \mathrm{O}$} & $\begin{array}{l}\mathrm{CuN}_{3} \\
\mathrm{CuN}_{3}\end{array}$ & $\begin{array}{l}\text { TP } \\
\text { TP }\end{array}$ & $\begin{array}{l}1.928-2.002 \\
1.934-2.000\end{array}$ & - & Exo-tridentate $(2 \times)$ & $1-\mathrm{D}$ & [40] \\
\hline KEMLEV & {$\left[\mathrm{Cu}\left(\operatorname{tr}_{2} \mathrm{ad}\right)\left(\mathrm{SO}_{4}\right)\right] \cdot 3 \mathrm{H}_{2} \mathrm{O}$} & trans- $\mathrm{CuN}_{4} \mathrm{O}_{2}$ & OC & $2.009-2.012$ & 2.406 & Exo-tetradentate & 2-D & [41] \\
\hline KEMLIZ & {$\left[\mathrm{Cu}_{3}\left(\operatorname{tr}_{2} \mathrm{ad}\right)_{4}\left(\mathrm{H}_{2} \mathrm{O}\right)_{2}\left(\mathrm{SO}_{4}\right)_{2}\right]\left(\mathrm{SO}_{4}\right) \cdot 28 \mathrm{H}_{2} \mathrm{O}$} & $\begin{array}{c}\mathrm{CuN}_{6} \\
\mathrm{CuN}_{4} \mathrm{O}\end{array}$ & $\begin{array}{l}\mathrm{OC} \\
\mathrm{SQP}\end{array}$ & $\begin{array}{l}2.024-2.365 \\
1.995-2.223\end{array}$ & $\begin{array}{c}- \\
1.958\end{array}$ & $\begin{array}{l}\text { Exo-tetradentate } \\
\text { Exo-tridentate }\end{array}$ & 2-D & [41] \\
\hline KEMLOF & {$\left[\mathrm{Cu}_{3}\left(\operatorname{tr}_{2} \mathrm{ad}\right)_{4}\left(\mathrm{H}_{2} \mathrm{O}\right)_{2}\right]\left(\mathrm{SiF}_{6}\right)_{3} \cdot 16 \mathrm{H}_{2} \mathrm{O}$} & $\begin{array}{c}\mathrm{CuN}_{6} \\
\text { cis--CuN } \\
4\end{array}$ & $\begin{array}{l}\text { OC } \\
\text { OC }\end{array}$ & $\begin{array}{l}2.001-2.413 \\
1.988-2.269\end{array}$ & $\begin{array}{c}- \\
1.987,2.554\end{array}$ & $\begin{array}{l}\text { Exo-tetradentate } \\
\text { Exo-tridentate }\end{array}$ & 2-D & [41] \\
\hline PODMAX & {$\left[\mathrm{Cu}_{4}\left(\operatorname{tr}_{2} \mathrm{ad}\right)_{2}(\mathrm{btc})_{2}\left(\mu_{3}-\mathrm{OH}\right)_{2}\right]$} & $\begin{array}{l}\mathrm{CuNO}_{4} \\
\mathrm{CuN}_{2} \mathrm{O}_{3}\end{array}$ & $\begin{array}{c}\mathrm{SQP} \\
\mathrm{TB}\end{array}$ & $\begin{array}{c}2.411 \\
1.989-2.010\end{array}$ & $\begin{array}{l}1.915-1.999 \\
1.953-2.165\end{array}$ & Exo-tridentate & $3-\mathrm{D}$ & [44] \\
\hline SERCUP & {$\left[\mathrm{Cu}_{4}\left(\operatorname{tr}_{2} \mathrm{ad}\right)_{2}(\mathrm{H}-\mathrm{adtc})_{2}(\mathrm{OH})_{2}\left(\mathrm{H}_{2} \mathrm{O}\right)_{2}\right] \cdot 4 \mathrm{H}_{2} \mathrm{O}$} & $\begin{array}{c}\mathrm{CuNO}_{5} \\
\text { cis- } \mathrm{CuN}_{2} \mathrm{O}_{4} \\
\mathrm{CuN}_{2} \mathrm{O}_{3} \\
\mathrm{CuNO}_{4}\end{array}$ & $\begin{array}{l}\text { OC } \\
\text { OC } \\
\text { SQP } \\
\text { SQP }\end{array}$ & $\begin{array}{c}1.981 \\
1.989-2.334 \\
2.005-2.271 \\
1.987\end{array}$ & $\begin{array}{l}1.905-2.685 \\
1.957-2.691 \\
1.950-1.996 \\
1.923-2.279\end{array}$ & Exo-tridentate & 2-D & [45] \\
\hline TUGSUK & {$\left[\mathrm{Cu}_{3}\left(\operatorname{tr}_{2} \mathrm{ad}\right)_{4}\left(\mathrm{SO}_{4}\right)\left(\mathrm{H}_{2} \mathrm{O}\right)_{3}\right]\left(\mathrm{SO}_{4}\right)_{2} \cdot 34 \mathrm{H}_{2} \mathrm{O}$} & $\begin{array}{c}\mathrm{CuN}_{6} \\
\text { cis- } \mathrm{CuN}_{4} \mathrm{O}_{2} \\
\mathrm{CuN}_{4} \mathrm{O}\end{array}$ & $\begin{array}{c}\mathrm{OC} \\
\mathrm{OC} \\
\mathrm{SQP}\end{array}$ & $\begin{array}{l}1.989-2.295 \\
1.990-2.250 \\
1.957-2.291\end{array}$ & $\begin{array}{c}- \\
1.989,2.408 \\
1.989\end{array}$ & $\begin{array}{l}\text { Exo-tetradentate }(2 \times) \\
\text { Exo-tridentate }(2 \times)\end{array}$ & $3-\mathrm{D}$ & [46] \\
\hline TUGTAR & {$\left[\mathrm{Cu}_{2}(\mu-\mathrm{OH})\left(\operatorname{tr}_{2} \mathrm{ad}\right)_{2}\right]\left(\mathrm{NO}_{3}\right)_{3} \cdot 4 \mathrm{H}_{2} \mathrm{O}$} & $\begin{array}{c}\mathrm{CuN}_{6} \\
\text { cis- } \mathrm{CuN}_{4} \mathrm{O}_{2} \\
\text { trans-CuN } \\
\text { tra }\end{array}$ & $\begin{array}{l}\text { OC } \\
\text { OC } \\
\text { OC }\end{array}$ & $\begin{array}{c}2.026-2.527 \\
1.982-2.212 \\
2.000\end{array}$ & $\begin{array}{c}- \\
1.921-2.788 \\
1.909-2.686\end{array}$ & Exo-tetradentate $(2 \times)$ & $3-\mathrm{D}$ & [46] \\
\hline ILUFEB & {$\left[\mathrm{Cd}_{3}\left(\operatorname{tr}_{2} \mathrm{ad}\right)_{3}\right](\mathrm{SeCN})_{6}$} & $\begin{array}{l}\mathrm{CdN}_{6} \\
\mathrm{CdN}_{6}\end{array}$ & $\begin{array}{l}\text { OC } \\
\text { OC }\end{array}$ & $\begin{array}{l}2.289-2.370 \\
2.332-2.353\end{array}$ & $\begin{array}{l}- \\
-\end{array}$ & Exo-tridentate $(4 \times)$ & $3-\mathrm{D}$ & [47] \\
\hline KEHDEI & {$\left[\mathrm{Cd}_{2}\left(\operatorname{tr}_{2} \mathrm{ad}\right)_{2}\left(\mathrm{H}_{2} \mathrm{O}\right)_{4}\right]\left(\mathrm{CdBr}_{4}\right)_{2}$} & $\begin{array}{c}\text { cis- } \mathrm{CdN}_{4} \mathrm{O}_{2} \\
\text { cis- } \mathrm{CdN}_{4} \mathrm{O}_{2} \\
\mathrm{CdBr}_{4}\end{array}$ & $\begin{array}{l}\text { OC } \\
\text { OC } \\
\text { TD }\end{array}$ & $\begin{array}{c}2.266-2.343 \\
2.273-2.323 \\
-\end{array}$ & $\begin{array}{l}2.377-2.382 \\
2.370-2.406 \\
2.567-2.629\end{array}$ & Exo-bidentate $(4 \times)$ & $3-\mathrm{D}$ & [48] \\
\hline
\end{tabular}


Table 1. Cont

\begin{tabular}{|c|c|c|c|c|c|c|c|c|}
\hline CSD Code & Molecular Formula & M Stereochemistry & M Geometry & M-N (Å) & M-X (Å) & $\operatorname{Tr}_{2}$ ad Apticity & Dim. & Ref. \\
\hline KEHDIM & {$\left[\mathrm{Cd}_{3}\left(\operatorname{tr}_{2} \mathrm{ad}\right)_{2} \mathrm{I}_{6}\right]$} & $\begin{array}{l}\mathrm{CdN}_{6} \\
\mathrm{CdNI}_{3} \\
\end{array}$ & $\begin{array}{l}\mathrm{OC} \\
\mathrm{TD}\end{array}$ & $\begin{array}{c}2.305-2.403 \\
2.283 \\
\end{array}$ & $\begin{array}{c}- \\
2.744-2.756 \\
\end{array}$ & Exo-bidentate $(2 \times)$ & 2-D & [48] \\
\hline TUGSIY & {$\left[\mathrm{Cd}_{3}\left(\operatorname{tr}_{2} \mathrm{ad}\right)_{3}(\mu-\mathrm{NCS})_{3}\right](\mathrm{NCS})_{3}$} & $\begin{array}{c}\mathrm{CdN}_{1-\mathrm{x}} \mathrm{S}_{\mathrm{x}}(0<\mathrm{x}<1) \\
\mathrm{CdN}_{6}\end{array}$ & $\begin{array}{l}\text { OC } \\
\text { OC }\end{array}$ & $\begin{array}{l}2.296-2.473 \\
2.312-2.405\end{array}$ & 2.662 & Exo-tetradentate $(3 \times)$ & $2-\mathrm{D}$ & [46] \\
\hline TUGSOE & {$\left[\mathrm{Cd}_{3}\left(\operatorname{tr}_{2} \mathrm{ad}\right)_{6}\right]\left(\mathrm{NO}_{3}\right)_{6} \cdot 22 \mathrm{H}_{2} \mathrm{O}$} & $\begin{array}{l}\mathrm{CdN}_{6} \\
\mathrm{CdN}_{6}\end{array}$ & $\begin{array}{l}\mathrm{OC} \\
\mathrm{OC}\end{array}$ & $\begin{array}{l}2.324-2.356 \\
2.297-2.381\end{array}$ & - & Exo-tridentate $(3 \times)$ & $3-\mathrm{D}$ & [46] \\
\hline HUSQES & $\left.\left[\mathrm{Mo}_{2}\left(\operatorname{tr}_{2} \mathrm{ad}\right) \mathrm{O}_{6}\right)\right] \cdot 6 \mathrm{H}_{2} \mathrm{O}$ & cis- $\mathrm{MoN}_{2} \mathrm{O}_{4}$ & OC & $2.366,2.375$ & $1.702-1.932$ & Exo-tetradentate & $3-\mathrm{D}$ & [49] \\
\hline LUYRII & $\left.\left[\mathrm{Mo}_{2}\left(\operatorname{tr}_{2} \mathrm{ad}\right) \mathrm{O}_{6}\right)\right] \cdot \mathrm{H}_{2} \mathrm{O}$ & cis- $\mathrm{MoN}_{2} \mathrm{O}_{4}$ & OC & 2.405 & $1.714-1.910$ & Exo-tetradentate & 2-D & [50] \\
\hline UZAKIQ & {$\left[\mathrm{Mo}_{2}\left(\operatorname{tr}_{2} \mathrm{ad}\right) \mathrm{F}_{2} \mathrm{O}_{5}\right]$} & $\begin{array}{l}\mathrm{MoN}_{2} \mathrm{O}_{3} \mathrm{~F} \\
\mathrm{MoN}_{2} \mathrm{O}_{3} \mathrm{~F}\end{array}$ & OC & 2.380 & $\begin{array}{c}1.710-1.918 \\
1.917^{\mathrm{a}} \\
1.706-1.914 \\
1.934^{\mathrm{a}} \\
\end{array}$ & Exo-tetradentate & 1-D/2-D & [51] \\
\hline VEPDEB & $\left\{\mathrm{Fe}_{3}\left(\operatorname{tr}_{2} \mathrm{ad}\right)_{4}\left[\mathrm{Au}(\mathrm{CN})_{2}\right]_{2}\right\}\left[\mathrm{Au}(\mathrm{CN})_{2}\right]_{4} \cdot 8 \mathrm{H}_{2} \mathrm{O}$ & $\begin{array}{l}\mathrm{FeN}_{6} \\
\mathrm{FeN}_{6}\end{array}$ & $\begin{array}{l}\text { OC } \\
\text { OC }\end{array}$ & $\begin{array}{l}1.910-1.970 \\
1.975-1.987 \\
\end{array}$ & $\begin{array}{l}- \\
- \\
\end{array}$ & $\begin{array}{l}\text { Exo-tetradentate }(2 \times) \\
\text { Exo-tridentate }\end{array}$ & $3-\mathrm{D}$ & {$[52]$} \\
\hline KEHDOS & {$\left[\mathrm{Ag}\left(\operatorname{tr}_{2} \mathrm{ad}\right)\right]\left(\mathrm{NO}_{3}\right) \cdot \mathrm{H}_{2} \mathrm{O}$} & $\begin{array}{l}\mathrm{AgN}_{4} \\
\mathrm{AgN}_{4} \\
\end{array}$ & $\begin{array}{l}\text { TD } \\
\text { TD }\end{array}$ & $\begin{array}{l}2.185-2.502 \\
2.185-2.528 \\
\end{array}$ & - & Exo-tetradentate $(2 \times)$ & $3-\mathrm{D}$ & [48] \\
\hline WEJWAL & {$\left[\mathrm{Ag}\left(\operatorname{tr}_{2} \mathrm{ad}\right)\right]\left(\mathrm{ClO}_{4}\right)$} & $\mathrm{AgN}_{3}$ & $\mathrm{TP}$ & $2.191-2.347$ & - & Exo-tridentate & 2-D & [53] \\
\hline WEJWEP & {$\left[\mathrm{Ag}_{2}\left(\operatorname{tr}_{2} \mathrm{ad}\right)_{2}\left(\mathrm{VO}_{2} \mathrm{~F}_{2}\right)_{2}\right] \cdot \mathrm{H}_{2} \mathrm{O}$} & $\mathrm{AgN}_{3} \mathrm{O}$ & $\mathrm{TD}$ & $2.209-2.464$ & 2.558 & Exo-tetradentate & $1-\mathrm{D}$ & [53] \\
\hline
\end{tabular}




\section{Materials and Methods}

\subsection{General}

All reagents and solvents were purchased from Sigma-Aldrich (Darmstadt, Germany) and used as received, without further purification. The ligand 1,3-bis(1,2,4-triazol-4-yl)adamantane $\left(\operatorname{tr}_{2} \mathrm{ad}\right)$ was synthesized by the acid-catalyzed condensation reaction of 1,3-diaminoadamantane and $N, N$-dimethylformamide azine, according to an already reported method [46]. A detailed description regarding the preparation of the intermediates (Scheme S1), on which no details have ever been reported before, is provided in the Supplementary Materials. NMR spectra (DMSO- $d_{6}, \delta$, ppm) were recorded on a Bruker $400 \mathrm{MHz}$ spectrometer. The IR spectra were recorded from 4000 to $650 \mathrm{~cm}^{-1}$ with a PerkinElmer Spectrum 100 instrument (Perkin-Elmer, Shelton, CT, USA) by attenuated total reflectance on a CdSe crystal. Elemental analyses (carbon, hydrogen, and nitrogen \%) were performed with a Fisons Instruments 1108 CHNS-O elemental analyzer (Thermo Scientific, Waltham, MA, USA). Before the analytical characterization was carried out, all the samples were dried under vacuum $\left(50{ }^{\circ} \mathrm{C}\right.$, $\sim 0.1$ Torr) until a constant weight was reached. Thermogravimetric analyses (TGAs) were carried out under a $\mathrm{N}_{2}$ flow $\left(25 \mathrm{~mL} / \mathrm{min}\right.$ ), in the temperature range $30-700{ }^{\circ} \mathrm{C}$ and with a heating rate of $5{ }^{\circ} \mathrm{C} / \mathrm{min}$, using a PerkinElmer STA 6000 simultaneous thermal analyzer (Perkin-Elmer, Shelton, CT, USA).

\subsection{Synthesis of the $\mathrm{Tr}_{2}$ ad-Based CPS}

\subsubsection{Synthesis of $\left[\mathrm{Zn}\left(\operatorname{tr}_{2} \mathrm{ad}\right) \mathrm{Cl}_{2}\right]_{n}$}

$\operatorname{Tr}_{2}$ ad $(0.054 \mathrm{~g}, 0.2 \mathrm{mmol})$ was dissolved in $N, N$-dimethylformamide (DMF) $(5 \mathrm{~mL})$ and the obtained solution was left under stirring at room temperature for $5 \mathrm{~min}$. Then, $\mathrm{ZnCl}_{2} \cdot 2 \mathrm{H}_{2} \mathrm{O}(0.017 \mathrm{~g}$, $0.1 \mathrm{mmol}$ ) was added, and the resulting solution was introduced into a high-pressure glass tube and heated at $150{ }^{\circ} \mathrm{C}$ for $24 \mathrm{~h}$. Slow cooling of the solution to room temperature, followed by partial slow evaporation of the solvent, afforded a white solid which was filtered off, washed twice with DMF, dried under vacuum and identified as $\left[\mathrm{Zn}\left(\mathrm{tr}_{2} \mathrm{ad}\right) \mathrm{Cl}_{2}\right]$. Yield: $55 \%$. [ $\left.\mathrm{Zn}\left(\operatorname{tr}_{2} \mathrm{ad}\right) \mathrm{Cl}_{2}\right]$ is insoluble in alcohols, acetone, acetonitrile, chlorinated solvents, DMF, dimethylsulfoxide (DMSO) and water. Elem. anal. calc. for $\mathrm{C}_{14} \mathrm{H}_{18} \mathrm{Cl}_{2} \mathrm{~N}_{6} \mathrm{Zn}(\mathrm{FW}=406.65 \mathrm{~g} / \mathrm{mol}): \mathrm{C}, 41.35 ; \mathrm{H}, 4.46 ; \mathrm{N}, 20.67 \%$. Found: C, 40.95; H, 4.23; N, 20.35\%. IR ( $\left.\mathrm{cm}^{-1}\right): 3160(\mathrm{w}), 3110(\mathrm{~m}) \vee\left(\mathrm{C}-\mathrm{H}_{\text {aromatic }}\right), 2930(\mathrm{~m}), 2870(\mathrm{~m}) \vee\left(\mathrm{C}-\mathrm{H}_{\text {aliphatic }}\right), 1539(\mathrm{~s}) v(\mathrm{C}=\mathrm{N})$, 1387(m), 1329(m), 1192(vs), 1110(m), 1029(vs), 973(w), 883(m), 934(m), 786(w), 728(m), 680(m), 656(vs).

\subsubsection{Synthesis of $\left\{\left[\mathrm{Cu}\left(\operatorname{tr}_{2} \mathrm{ad}\right) \mathrm{Cl}\right] \mathrm{Cl} \cdot 4 \mathrm{H}_{2} \mathrm{O}\right\}_{n}$}

$\operatorname{Tr}_{2}$ ad $(0.054 \mathrm{~g}, 0.2 \mathrm{mmol})$ was dissolved in DMF $(5 \mathrm{~mL})$ and the obtained solution was left under stirring at room temperature for $5 \mathrm{~min}$. Then, $\mathrm{CuCl}_{2}(0.013 \mathrm{~g}, 0.1 \mathrm{mmol})$ was added, and the resulting solution was introduced into a high-pressure glass tube and heated at $150{ }^{\circ} \mathrm{C}$ for $24 \mathrm{~h}$. Slow cooling of the solution to room temperature, followed by slow partial evaporation of the solvent, afforded a light blue solid which was filtered off, washed twice with DMF, dried under vacuum and identified as $\left[\mathrm{Cu}\left(\operatorname{tr}_{2} \mathrm{ad}\right) \mathrm{Cl}\right] \mathrm{Cl} \cdot 4 \mathrm{H}_{2} \mathrm{O}$. Yield: $65 \%$. $\left[\mathrm{Cu}\left(\operatorname{tr}_{2} \mathrm{ad}\right) \mathrm{Cl}\right] \mathrm{Cl} \cdot 4 \mathrm{H}_{2} \mathrm{O}$ is insoluble in alcohols, acetone, acetonitrile, chlorinated solvents, DMF, DMSO and water. Elem. anal. calc. for $\mathrm{C}_{14} \mathrm{H}_{26} \mathrm{Cl}_{2} \mathrm{CuN}_{6} \mathrm{O}_{4}$ $(\mathrm{FW}=476.91 \mathrm{~g} / \mathrm{mol}): \mathrm{C}, 35.26 ; \mathrm{H}, 5.49 ; \mathrm{N}, 17.62 \%$. Found: $\mathrm{C}, 34.85 ; \mathrm{H}, 5.33 ; \mathrm{N}, 17.25 \%$. IR $\left(\mathrm{cm}^{-1}\right)$ :

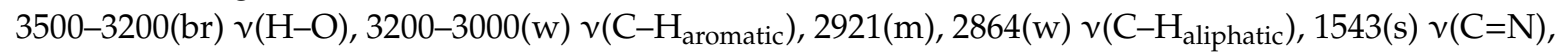
1346(s), 1207(vs), 1086(vs), 1045(w), 1021(w), 883(m), 842(w), 786(w), 728(m), 680(m).

\subsubsection{Synthesis of $\left[\mathrm{Cd}_{2}\left(\operatorname{tr}_{2} \mathrm{ad}\right) \mathrm{Cl}_{4}\right]_{n}$}

$\operatorname{Tr}_{2}$ ad $(0.054 \mathrm{~g}, 0.2 \mathrm{mmol})$ was dissolved in methanol $(5 \mathrm{~mL})$ and the obtained solution was left under stirring at room temperature for $5 \mathrm{~min}$. Then, $\mathrm{CdCl}_{2}(0.036 \mathrm{~g}, 0.2 \mathrm{mmol})$ was added, and the resulting solution was introduced into a high-pressure glass tube and heated at $100{ }^{\circ} \mathrm{C}$ for $24 \mathrm{~h}$. The white precipitate which was formed was filtered off, washed three times with hot methanol, dried under vacuum and identified as $\left[\mathrm{Cd}_{2}\left(\operatorname{tr}_{2} \mathrm{ad}\right) \mathrm{Cl}_{4}\right]$. Yield: $65 \%$. $\left[\mathrm{Cd}_{2}\left(\operatorname{tr}_{2} \mathrm{ad}\right) \mathrm{Cl}_{4}\right]$ is insoluble in 
alcohols, acetone, acetonitrile, chlorinated solvents, DMF, DMSO and water. Elem. anal. calc. for $\mathrm{C}_{14} \mathrm{H}_{18} \mathrm{Cd}_{2} \mathrm{Cl}_{4} \mathrm{~N}_{6}(\mathrm{FW}=637.00 \mathrm{~g} / \mathrm{mol}): \mathrm{C}, 26.40 ; \mathrm{H}, 2.85 ; \mathrm{N}, 13.19 \%$. Found: $\mathrm{C}, 26.33 ; \mathrm{H}, 2.92 ; \mathrm{N}$, $12.85 \%$. IR $\left(\mathrm{cm}^{-1}\right): 3143(\mathrm{w}), 3121(\mathrm{~m}) v\left(\mathrm{C}-\mathrm{H}_{\text {aromatic }}\right), 2915(\mathrm{~m}), 2858(\mathrm{w}) v\left(\mathrm{C}-\mathrm{H}_{\text {aliphatic }}\right), 1737(\mathrm{~m}), 1534(\mathrm{~m})$ $v(\mathrm{C}=\mathrm{N}), 1371(\mathrm{~m}), 1253(\mathrm{~m}), 1191(\mathrm{vs}), 1105(\mathrm{~m}), 1069(\mathrm{~s}), 1046(\mathrm{vs}), 990(\mathrm{~m}), 883(\mathrm{~m}), 866(\mathrm{~m}), 850(\mathrm{~m}), 791(\mathrm{w})$, 730(m), 681(m), 658(m).

\subsubsection{Synthesis of $\left\{\left[\mathrm{Cu}\left(\operatorname{tr}_{2} \mathrm{ad}\right)\left(\mathrm{NO}_{3}\right)\right]\left(\mathrm{NO}_{3}\right)\right\}_{n}$}

$\operatorname{Tr}_{2}$ ad $(0.054 \mathrm{~g}, 0.2 \mathrm{mmol})$ was dissolved in methanol $(5 \mathrm{~mL})$ and the obtained solution was left under stirring at room temperature for $5 \mathrm{~min}$. Then, $\mathrm{Cu}\left(\mathrm{NO}_{3}\right)_{2} \cdot 2.5 \mathrm{H}_{2} \mathrm{O}(0.037 \mathrm{~g}, 0.2 \mathrm{mmol})$ was added, and the resulting solution was introduced into a high-pressure glass tube and heated at $100{ }^{\circ} \mathrm{C}$ for $24 \mathrm{~h}$. A green precipitate was formed, which was filtered off, washed three times with hot methanol, dried under vacuum and identified as $\left[\mathrm{Cu}\left(\operatorname{tr}_{2} \mathrm{ad}\right)\left(\mathrm{NO}_{3}\right)\right]\left(\mathrm{NO}_{3}\right)$. Yield: $70 \%$. $\left[\mathrm{Cu}\left(\operatorname{tr}_{2} \mathrm{ad}\right)\left(\mathrm{NO}_{3}\right)\right]\left(\mathrm{NO}_{3}\right)$ is insoluble in alcohols, acetone, acetonitrile, chlorinated solvents, DMF, DMSO and water. Elem. Anal. calc. for $\mathrm{C}_{14} \mathrm{H}_{18} \mathrm{CuN}_{8} \mathrm{O}_{6}(\mathrm{FW}=457.95 \mathrm{~g} / \mathrm{mol})$ : $\mathrm{C}, 36.72 ; \mathrm{H}, 3.96 ; \mathrm{N}, 24.47 \%$. Found: $\mathrm{C}, 36.35$; $\mathrm{H}, 3.73$; N, 24.19\%. IR ( $\left.\mathrm{cm}^{-1}\right): 3136(\mathrm{~m}), 3016(\mathrm{vw}) \vee\left(\mathrm{C}-\mathrm{H}_{\text {aromatic }}\right), 2916(\mathrm{~m}), 2856(\mathrm{w}) \vee\left(\mathrm{C}-\mathrm{H}_{\text {aliphatic }}\right)$, 1755(vw), 1733(vw), 1551(s) $v(\mathrm{C}=\mathrm{N}), 1439(\mathrm{~s}) v_{\text {asym }}$ (coordinated $\left.\mathrm{NO}_{3}\right), 1394(\mathrm{vs}) v_{\text {asym }}$ (uncoordinated $\left.\mathrm{NO}_{3}\right), 1346(\mathrm{vs}) v_{\text {sym }}\left(\right.$ uncoordinated $\left.\mathrm{NO}_{3}\right), 1329(\mathrm{vs}), 1282(\mathrm{vs}) v_{\text {sym }}\left(\right.$ coordinated $\left.\mathrm{NO}_{3}\right), 1210(\mathrm{~s}), 1180(\mathrm{~m})$, 1119(w), 1089(s), 1073(m), 1054(m), 1019(s), 867(vs), 826(m), 787(w), 738(m), 716(w), 681(m).

\subsubsection{Synthesis of $\left\{\left[\mathrm{Cd}\left(\operatorname{tr}_{2} \mathrm{ad}\right)\left(\mathrm{NO}_{3}\right)\right]\left(\mathrm{NO}_{3}\right) \cdot \mathrm{H}_{2} \mathrm{O}\right\}_{n}$}

$\operatorname{Tr}_{2}$ ad $(0.054 \mathrm{~g}, 0.2 \mathrm{mmol})$ was dissolved in methanol $(5 \mathrm{~mL})$ and the obtained solution was left under stirring at room temperature for $5 \mathrm{~min}$. Then, $\mathrm{Cd}\left(\mathrm{NO}_{3}\right)_{2} \cdot 4 \mathrm{H}_{2} \mathrm{O}(0.047 \mathrm{~g}, 0.2 \mathrm{mmol})$ was added, and the resulting solution was introduced into a high pressure glass tube and heated at $100{ }^{\circ} \mathrm{C}$ for $24 \mathrm{~h}$. The white precipitate which was formed was filtered off, washed three times with hot methanol, dried under vacuum and identified as $\left[\mathrm{Cd}\left(\operatorname{tr}_{2} \mathrm{ad}\right)\left(\mathrm{NO}_{3}\right)\right]\left(\mathrm{NO}_{3}\right) \cdot \mathrm{H}_{2} \mathrm{O}$. Yield: $60 \%$. $\left[\mathrm{Cd}\left(\operatorname{tr}_{2} \mathrm{ad}\right)\left(\mathrm{NO}_{3}\right)\right]\left(\mathrm{NO}_{3}\right) \cdot \mathrm{H}_{2} \mathrm{O}$ is insoluble in alcohols, acetone, acetonitrile, chlorinated solvents, DMF, DMSO and water. Elem. Anal. calc. for $\mathrm{C}_{14} \mathrm{H}_{20} \mathrm{CdN}_{8} \mathrm{O}_{7}(\mathrm{FW}=524.83 \mathrm{~g} / \mathrm{mol})$ : $\mathrm{C}, 32.04 ; \mathrm{H}, 3.84 ; \mathrm{N}, 21.35 \%$. Found: $\mathrm{C}, 31.87$; $\mathrm{H}, 3.55 ; \mathrm{N}, 20.98 \%$. IR ( $\left.\mathrm{cm}^{-1}\right)$ : 3418(br) $v(\mathrm{H}-\mathrm{O}), 3098(\mathrm{w}), 3043(\mathrm{w}) \vee\left(\mathrm{C}-\mathrm{H}_{\text {aromatic }}\right), 2916(\mathrm{~m}), 2869(\mathrm{w})$, 2853(w) $v\left(\mathrm{C}-\mathrm{H}_{\text {aliphatic }}\right), 1748(\mathrm{vw}), 1717(\mathrm{vw}), 1633(\mathrm{w}), 1543(\mathrm{~m}) \vee(\mathrm{C}=\mathrm{N}), 1478(\mathrm{~s}) v_{\text {asym }}$ (coordinated $\left.\mathrm{NO}_{3}\right), 1374(\mathrm{vs}) v_{\text {asym }}$ (uncoordinated $\left.\mathrm{NO}_{3}\right), 1339(\mathrm{vs}) v_{\text {sym }}$ (uncoordinated $\left.\mathrm{NO}_{3}\right), 1301(\mathrm{vs}), 1275(\mathrm{vs})$ $v_{\text {sym }}\left(\right.$ coordinated $\left.\mathrm{NO}_{3}\right), 1208(\mathrm{vs}), 1174(\mathrm{~m}), 1110(\mathrm{w}), 1076(\mathrm{~m}), 1037(\mathrm{vs}), 998(\mathrm{vs}), 851(\mathrm{~m}), 828(\mathrm{~m}), 789(\mathrm{w})$, 731(s), 683(s).

\subsection{X-ray Diffraction Structural Analysis}

\subsubsection{Structural Analysis of $\operatorname{tr}_{2} \mathrm{ad}$ and $\operatorname{tr}_{2} \mathrm{ad} \cdot 3 \mathrm{H}_{2} \mathrm{O}$}

The $\mathrm{X}$-ray diffraction data of $\operatorname{tr}_{2}$ ad (colorless prism with dimensions of $0.27 \times 0.22 \times 0.20 \mathrm{~mm}$ ) and $\operatorname{tr}_{2} \mathrm{ad} \cdot 3 \mathrm{H}_{2} \mathrm{O}$ (colorless prism with dimensions of $0.33 \times 0.16 \times 0.13 \mathrm{~mm}$ ) were collected at $173 \mathrm{~K}$ on a Bruker APEXII area-detector diffractometer (Bruker, Billerica, MA, USA) equipped with a sealed X-ray tube (Mo-K $\alpha$ radiation, $\lambda=0.71073 \AA$ ). The data were corrected for Lorentz-polarization effects and for the effects of absorption (multi-scans method). The crystal structures were solved by direct methods and refined against $F^{2}$ using the programs SHELXS-97 or SHELXL-2018/1 [54,55]. The non-hydrogen atoms were assigned anisotropic thermal displacement parameters. All the hydrogen atoms were located in difference Fourier maps and then refined freely with isotropic thermal displacement parameters and with soft similarity restraints applied to $\mathrm{O}-\mathrm{H}$ bond lengths in the structure of $\operatorname{tr}_{2}$ ad $33 \mathrm{H}_{2} \mathrm{O}$.

Crystal data for $\operatorname{tr}_{2} \mathrm{ad}, \mathrm{FW}=270.34 \mathrm{~g} \mathrm{~mol}^{-1}$ : monoclinic, $P 2_{1} / n, a=8.9372(4) \AA, b=8.7877(5) \AA$, $c=16.8366(8) \AA, \beta=97.888(2)^{\circ}, V=1309.79(11) \AA^{3}, Z=4, \rho=1.371 \mathrm{~g} \mathrm{~cm}^{-3}, F(000)=576, R 1=0.039$, $\mathrm{w} R 2=0.095[I>2 \sigma(I)]$ and $R 1=0.053, \mathrm{w} R 2=0.1032$ (all data) for 2656 data and 253 parameters in the 4.9-52.8 $2 \theta$ range. CCDC No. 2034960. 
Crystal data for $\operatorname{tr}_{2} \mathrm{ad} \cdot 3 \mathrm{H}_{2} \mathrm{O}, \mathrm{FW}=324.39 \mathrm{~g} \mathrm{~mol}^{-1}$ : orthorhombic, Pnma, $a=9.6759(10) \AA$, $b=16.3052(8) \AA, c=10.0229(11) \AA, V=1581.3(3) \AA^{3}, Z=4, \rho=1.363 \mathrm{~g} \mathrm{~cm}^{-3}, F(000)=696, R 1=0.049$, $\mathrm{w} R 2=0.087[I>2 \sigma(I)]$ and $R 1=0.110, \mathrm{w} R 2=0.104$ (all data) for 1656 data and 164 parameters in the $4.8-52.8^{\circ} 2 \theta$ range. CCDC No. 2034961.

\subsubsection{Structural Analysis of the Coordination Polymers}

Powdered samples ( $50 \mathrm{mg}$ ) of the five CPs were deposited in the cavity of a silicon free-background sample-holder $0.2 \mathrm{~mm}$ deep (Assing S.r.l., Monterotondo, Italy). Powder X-ray diffraction (PXRD) data acquisitions were carried out with a Bruker AXS D8 Advance vertical-scan $\theta: \theta$ diffractometer (Bruker, Billerica, MA, USA), equipped with a sealed X-ray tube $(\mathrm{Cu}-\mathrm{K} \alpha, \lambda=1.5418 \AA$ ), a Bruker Lynxeye linear position-sensitive detector, a filter of nickel in the diffracted beam and the following optical components: primary beam Soller slits (aperture $2.5^{\circ}$ ), fixed divergence slit (aperture $0.5^{\circ}$ ), anti-scatter slit (aperture $8 \mathrm{~mm}$ ). The generator was set at $40 \mathrm{kV}$ and $40 \mathrm{~mA}$. Preliminary PXRD analyses to unveil the purity and crystallinity of the samples were performed in the $2 \theta$ range $3.0-35.0^{\circ}$, with steps of $0.02^{\circ}$ and time per step of $1 \mathrm{~s}$. PXRD acquisitions for the assessment of the crystal structure were performed in the $2 \theta$ range $5.0-105.0^{\circ}$, with steps of $0.02^{\circ}$ and time per step of $10 \mathrm{~s}$. After a standard peak search, enabling us to assess the maximum position of the 20-25 lower-angle peaks, indexing was performed applying the Singular Value Decomposition approach [56] implemented in TOPAS-R V3 [57]. The space groups were assigned based on the systematic absences. The crystallographically independent portion of the $\operatorname{tr}_{2}$ ad ligand and nitrate anion were described using rigid bodies built up through the z-matrix formalism, assigning average values to the bond distances and angles (For $\operatorname{tr}_{2}$ ad: $\mathrm{C}_{\mathrm{ad}} / \mathrm{tz}_{\mathrm{z}}-\mathrm{C}_{\mathrm{ad}}=1.55 \AA, \mathrm{C}_{\mathrm{tz}}-\mathrm{N}_{\mathrm{tz}}, \mathrm{N}_{\mathrm{tz}}-\mathrm{N}_{\mathrm{tz}}=1.36 \AA, \mathrm{C}-\mathrm{H}=0.95 \AA$; Triazole Internal and External Bond Angles $=108$ and $126^{\circ}$; Angles at the $\mathrm{C}_{\mathrm{ad}}$ Atoms $=109.5^{\circ}$. For the Nitrate Anion: $\mathrm{N}-\mathrm{O}=1.30 \AA$; $\mathrm{O}-\mathrm{N}-\mathrm{O}=120^{\circ}$.). The structures were solved working in the real space with the Simulated Annealing approach [58], as implemented in TOPAS-R V3. Structures refinement was carried out with the Rietveld method [59], as implemented in TOPAS-R V3. The background was modelled through a polynomial function of the Chebyshev type. An isotropic thermal factor $\left[\mathrm{B}_{\mathrm{iso}}(\mathrm{M})\right]$ was refined for the metal centres; the isotropic thermal factor of lighter atoms was calculated as $B_{\text {iso }}(L)=B_{\text {iso }}(M)+2.0\left(\AA^{2}\right)$. The peak profile was modelled trough the Fundamental Parameters Approach [60]. The anisotropic shape of the peaks was modelled with the aid of spherical harmonics in all the cases. A correction was applied for preferred orientation adopting the March-Dollase model [61] in the case of $\left[\mathrm{Zn}\left(\operatorname{tr}_{2} \mathrm{ad}\right) \mathrm{Cl}_{2}\right]_{n}$ and $\left\{\left[\mathrm{Cu}\left(\operatorname{tr}_{2} \mathrm{ad}\right)\left(\mathrm{NO}_{3}\right)\right]\left(\mathrm{NO}_{3}\right)\right\}_{n}$ (along the [001] pole), as well as of $\left\{\left[\mathrm{Cd}\left(\operatorname{tr}_{2} \mathrm{ad}\right)\left(\mathrm{NO}_{3}\right)\right]\left(\mathrm{NO}_{3}\right) \cdot \mathrm{H}_{2} \mathrm{O}\right\}_{n}($ along the [100] pole). The final Rietveld refinement plots are shown in Figures S5-S9.

Crystal data for $\left[\mathrm{Zn}\left(\operatorname{tr}_{2} \mathrm{ad}\right) \mathrm{Cl}_{2}\right]_{n}, \mathrm{FW}=406.65 \mathrm{~g} \mathrm{~mol}^{-1}$ : orthorhombic, $P 2{ }_{1} 2_{1} 22_{1}, a=14.6240$ (3) $\AA$, $b=10.1054(2) \AA, c=11.1204(1) \AA, V=1643.40(5) \AA^{3}, Z=Z^{\prime}=4, \rho=1.64 \mathrm{~g} \mathrm{~cm}^{-3}, F(000)=832.0$, $R_{\text {Bragg }}=0.051, R_{\mathrm{p}}=0.057$ and $R_{\mathrm{wp}}=0.078$, for 4801 data and 46 parameters in the $9.0-105.0^{\circ} 2 \theta$ range. CCDC No. 2038425.

Crystal data for $\left\{\left[\mathrm{Cu}\left(\operatorname{tr}_{2} \mathrm{ad}\right) \mathrm{Cl}\right] \mathrm{Cl} \cdot 4 \mathrm{H}_{2} \mathrm{O}\right\}_{n}, \mathrm{FW}=476.91 \mathrm{~g} \mathrm{~mol}^{-1}$ : monoclinic, $P 21 / m, a=14.5644(9) \AA$, $b=7.1726(4) \AA, c=10.9798(6) \AA, \beta=122.820(3)^{\circ}, V=963.9(1) \AA^{3}, Z=4, Z^{\prime}=2, \rho=1.64 \mathrm{~g} \mathrm{~cm}^{-3}$, $F(000)=494.0, R_{\text {Bragg }}=0.019, R_{\mathrm{p}}=0.028$ and $R_{\mathrm{wp}}=0.040$, for 4951 data and 71 parameters in the 6.0-105.0 $2 \theta$ range. CCDC No. 2038423.

Crystal data for $\left[\mathrm{Cd}_{2}\left(\mathrm{tr}_{2} \mathrm{ad}\right) \mathrm{Cl}_{4}\right]_{n}, \mathrm{FW}=637.00 \mathrm{~g} \mathrm{~mol}^{-1}$ : triclinic, $P-1, a=6.9425(2) \AA$, $b=12.2352(3) \AA, c=12.6513(2) \AA, \alpha=115.621(1)^{\circ}, \beta=90.837(2)^{\circ}, \gamma=101.165(2)^{\circ}, V=944.74(4) \AA^{3}$, $Z=Z^{\prime}=2, \rho=2.24 \mathrm{~g} \mathrm{~cm}^{-3}, F(000)=616.0, R_{\mathrm{Bragg}}=0.050, R_{\mathrm{p}}=0.049$ and $R_{\mathrm{wp}}=0.068$, for 4901 data and 68 parameters in the $7.0-105.0^{\circ} 2 \theta$ range. CCDC No. 2038421.

Crystal data for $\left\{\left[\mathrm{Cu}\left(\operatorname{tr}_{2} \mathrm{ad}\right)\left(\mathrm{NO}_{3}\right)\right]\left(\mathrm{NO}_{3}\right)\right\}_{n}, \mathrm{FW}=457.95 \mathrm{~g} \mathrm{~mol}^{-1}$ : orthorhombic, Pnma, $a=7.0648(4) \AA$, $b=10.7226(5) \AA, c=22.495(1) \AA, V=1704.0(2) \AA^{3}, Z=8, Z^{\prime}=4, \rho=1.79 \mathrm{~g} \mathrm{~cm}^{-3}, F(000)=940.0, R_{\text {Bragg }}=0.025$, $R_{\mathrm{p}}=0.037$ and $R_{\mathrm{wp}}=0.048$, for 4951 data and 73 parameters in the 6.0-105.0 $2 \theta$ range. CCDC No. 2038424.

Crystal data for $\left\{\left[\mathrm{Cd}\left(\operatorname{tr}_{2} \mathrm{ad}\right)\left(\mathrm{NO}_{3}\right)\right]\left(\mathrm{NO}_{3}\right) \cdot \mathrm{H}_{2} \mathrm{O}\right\}_{n}, \mathrm{FW}=524.83 \mathrm{~g} \mathrm{~mol}^{-1}$ : monoclinic, $\mathrm{C} 2 / \mathrm{c}$, $a=23.181(1) \AA, b=11.3867(2) \AA, c=15.486(1) \AA, \beta=108.956(5)^{\circ}, V=3866.1(3) \AA^{3}, Z=Z^{\prime}=8$, 
$\rho=1.80 \mathrm{~g} \mathrm{~cm}^{-3}, F(000)=2112.0, R_{\mathrm{Bragg}}=0.047, R_{\mathrm{p}}=0.079$ and $R_{\mathrm{wp}}=0.110$, for 4901 data and 53 parameters in the $7.0-105.0^{\circ} 2 \theta$ range. CCDC No. 2038422.

\section{Conclusions}

In this work, we have described the synthesis and solid-state characterization of the novel coordination polymers (CPs) $\left[\mathrm{Zn}\left(\operatorname{tr}_{2} \mathrm{ad}\right) \mathrm{Cl}_{2}\right]_{n},\left\{\left[\mathrm{Cu}\left(\operatorname{tr}_{2} \mathrm{ad}\right) \mathrm{Cl}\right] \mathrm{Cl} \cdot 4 \mathrm{H}_{2} \mathrm{O}\right\}_{n},\left[\mathrm{Cd}_{2}\left(\operatorname{tr}_{2} \mathrm{ad}\right) \mathrm{Cl}_{4}\right]_{n},\left\{\left[\mathrm{Cu}\left(\operatorname{tr}_{2} \mathrm{ad}\right)\left(\mathrm{NO}_{3}\right)\right]\left(\mathrm{NO}_{3}\right)\right\}_{n}$ and $\left\{\left[\mathrm{Cd}\left(\operatorname{tr}_{2} \mathrm{ad}\right)\left(\mathrm{NO}_{3}\right)\right]\left(\mathrm{NO}_{3}\right) \cdot \mathrm{H}_{2} \mathrm{O}\right\}_{n}$ [ $\operatorname{tr}_{2} \mathrm{ad}=1,3$-bis(1,2,4-triazol-4-yl)adamantane], isolated as airand moisture-stable microcrystalline powders by means of solvothermal reactions. As assessed by thermogravimetric analysis, the five CPs show an appreciable thermal stability. As retrieved by powder X-ray diffraction, while $\left[\mathrm{Zn}\left(\operatorname{tr}_{2} \mathrm{ad}\right) \mathrm{Cl}_{2}\right]_{n}$ features 1-D chains, the other compounds contain 2-D double-layers. A comparative structural analysis involving known CPs built up with the $\operatorname{tr}_{2}$ ad ligand unveiled the coordination modes versatility of the ligand and the crystal structure dimensionality variability. Work can be anticipated in the functional characterization of these CPs as heterogeneous catalysts for cutting-edge organic reactions.

Supplementary Materials: The following are available online at http://www.mdpi.com/2304-6740/8/11/60/s1. Detailed synthesis of the $\operatorname{tr}_{2}$ ad ligand (Scheme S1). FTIR spectrum of $\operatorname{tr}_{2}$ ad (Figure S1). Ortep drawings for $\operatorname{tr}_{2} \mathrm{ad}$ and $\operatorname{tr}_{2} \mathrm{ad} \cdot 3 \mathrm{H}_{2} \mathrm{O}$ (Figure S2). Further representation of the crystal structure of $\left\{\left[\mathrm{Cu}\left(\operatorname{tr}_{2} \mathrm{ad}\right) \mathrm{Cl}\right] \mathrm{Cl} \cdot 4 \mathrm{H}_{2} \mathrm{O}\right\}_{n}$ (Figure S3). Comparison of bond distances at the metal ion (Figure S4). Graphical result of the final structure refinement carried out on $\left[\mathrm{Zn}\left(\operatorname{tr}_{2} \mathrm{ad}\right) \mathrm{Cl}_{2}\right]_{n},\left\{\left[\mathrm{Cu}\left(\operatorname{tr}_{2} \mathrm{ad}\right) \mathrm{Cl}\right] \mathrm{Cl} \cdot 4 \mathrm{H}_{2} \mathrm{O}\right\}_{n},\left[\mathrm{Cd}_{2}\left(\operatorname{tr}_{2} \mathrm{ad}\right) \mathrm{Cl}_{4}\right]_{n},\left\{\left[\mathrm{Cu}\left(\operatorname{tr}_{2} \mathrm{ad}\right)\left(\mathrm{NO}_{3}\right)\right]\left(\mathrm{NO}_{3}\right)\right\}_{n}$, and $\left\{\left[\mathrm{Cd}\left(\operatorname{tr}_{2} \mathrm{ad}\right)\left(\mathrm{NO}_{3}\right)\right]\left(\mathrm{NO}_{3}\right) \cdot \mathrm{H}_{2} \mathrm{O}\right\}_{n}$ (Figures S5-S9). The CIF files of $\operatorname{tr}_{2} \mathrm{ad}, \operatorname{tr}_{2} \mathrm{ad} \cdot 3 \mathrm{H}_{2} \mathrm{O}$ and the five CPs, and the checkCIF output files of $\operatorname{tr}_{2}$ ad and $\operatorname{tr}_{2}$ ad $3 \mathrm{H}_{2} \mathrm{O}$.

Author Contributions: Conceptualization, C.P. and S.G.; investigation: N.X., A.T., S.G., M.M., K.V.D. and G.A.S.; resources: K.V.D., C.P. and S.G.; writing-original draft preparation: A.T. and S.G.; writing-review and editing, A.T. and S.G.; supervision, C.P. and S.G. All authors have read and agreed to the published version of the manuscript.

Funding: This research received no external funding.

Acknowledgments: S.G. acknowledges Università dell'Insubria and C.P. acknowledges Università di Camerino for partial funding.

Conflicts of Interest: The authors declare no conflict of interest.

\section{References}

1. Hoskins, B.F.; Robson, R. Infinite polymeric frameworks consisting of three dimensionally linked rod-like segments. J. Am. Chem. Soc. 1989, 111, 5962-5964.

2. Morsali, A.; Hashemi, L. Main Group Metal Coordination Polymers: Structures and Nanostructures; John Wiley \& Sons Inc.: Hoboken, NJ, USA, 2017.

3. Patel, V. Synthesis, Characterization and Application of Coordination Polymers; Lambert Academic Publishing: Saarbrücken, Germany, 2015.

4. Batten, S.R.; Neville, S.M.; Turner, D.R. Coordination Polymers: Design, Analysis and Application; Springer: New York, NY, USA, 2010.

5. Hong, M.-C.; Chen, L. (Eds.) Design and Construction of Coordination Polymers; John Wiley \& Sons Inc.: Hoboken, NJ, USA, 2009.

6. Yaghi, O.M.; Kalmutzki, M.J.; Diercks, C.S. Introduction to Reticular Chemistry: Metal-Organic Frameworks and Covalent Organic Frameworks; Wiley-VCH: Weinheim, Germany, 2019.

7. Kaskel, S. (Ed.) The Chemistry of Metal-Organic Frameworks: Synthesis, Characterization, and Applications; Wiley-VCH: Weinheim, Germany, 2016.

8. MacGillivray, L.R.; Lukehart, C.M. (Eds.) Metal-Organic Framework Materials; Wiley-VCH: Weinheim, Germany, 2014.

9. Farrusseng, D. (Ed.) Metal-Organic Frameworks: Applications from Catalysis to Gas Storage; Wiley-VCH: New York, NY, USA, 2011.

10. Schröder, M. (Ed.) Functional Metal-Organic Frameworks: Gas Storage, Separation and Catalysis; Springer: Berlin, Germany, 2010. 
11. Li, H.; Wang, K.; Sun, Y.; Lollar, C.T.; Li, J.; Zhou, H.-C. Recent advances in gas storage and separation using metal-organic frameworks. Mater. Today 2018, 21, 108-121.

12. Rogge, S.M.J.; Bavykina, A.; Hajek, J.; Garcia, H.; Olivos-Suarez, A.I.; Sepúlveda-Escribano, A.; Vimont, A.; Clet, G.; Bazin, P.; Kapteijn, F.; et al. Metal-organic and covalent organic frameworks as single-site catalysts. Chem. Soc. Rev. 2017, 46, 3134-3184. [PubMed]

13. Kuznetsova, A.; Matveevskaya, V.; Pavlov, D.; Yakunenkov, A.; Potapov, A. Coordination polymers based on highly emissive ligands: Synthesis and functional properties. Materials 2020, 13, 2699.

14. Heine, J.; Müller-Buschbaum, K. Engineering metal-based luminescence in coordination polymers and metal-organic frameworks. Chem. Soc. Rev. 2013, 42, 9232-9242. [PubMed]

15. Sun, L.; Campbell, M.G.; Dincă, M. Electrically conductive porous metal-organic frameworks. Angew. Chem. Int. Ed. 2016, 55, 3566-3579.

16. Mínguez Espallargas, G.; Coronado, E. Magnetic functionalities in MOFs: From the framework to the pore. Chem. Soc. Rev. 2018, 47, 533-557.

17. Liu, J.-Q.; Luo, Z.-D.; Pan, Y.; Singh, A.K.; Trivedi, M.; Kumar, A. Recent developments in luminescent coordination polymers: Designing strategies, sensing application and theoretical evidences. Coord. Chem. Rev. 2020, 406, 213145.

18. Zhang, Y.; Yuan, S.; Day, G.; Wang, X.; Yang, X.; Zhou, H.-C. Luminescent sensors based on metal-organic frameworks. Coord. Chem. Rev. 2018, 354, 28-45.

19. Zhang, X.; Wang, W.; Hu, Z.; Wang, G.; Uvdal, K. Coordination polymers for energy transfer: Preparations, properties, sensing applications, and perspectives. Coord. Chem. Rev. 2015, 284, 206-235.

20. Wu, M.-X.; Yang, Y.-W. Metal-organic framework (MOF)-based drug/cargo delivery and cancer therapy. Adv. Mater. 2017, 29, 1606134.

21. Janiak, C.; Vieth, J.K. MOFs, MILs and more: Concepts, properties and applications for porous coordination networks (PCNs). New J. Chem. 2010, 34, 2366-2388.

22. Robin, A.Y.; Fromm, K.M. Coordination polymer networks with O-and N-donors: What they are, why and how they are made. Coord. Chem. Rev. 2006, 250, 2127-2157.

23. Kitagawa, S.; Kitaura, R.; Noro, S.-I. Functional porous coordination polymers. Angew. Chem. Int. Ed. 2004, 43, 2334-2375.

24. Biradha, K.; Sarkar, M.; Rajput, L. Crystal engineering of coordination polymers using 4,4'-bipyridine as a bond between transition metal atoms. Chem. Commun. 2006, 4169-4179. [CrossRef]

25. Gagnon, K.J.; Perry, H.P.; Clearfield, A. Conventional and unconventional metal-organic frameworks based on phosphonate ligands: MOFs and UMOFs. Chem. Rev. 2012, 112, 1034-1054.

26. Tabacaru, A.; Pettinari, C.; Galli, S. Coordination polymers and metal-organic frameworks built up with poly(tetrazolate) ligands. Coord. Chem. Rev. 2018, 372, 1-30.

27. Pettinari, C.; Tabacaru, A.; Galli, S. Coordination polymers and metal-organic frameworks based on poly(pyrazole)-containing ligands. Coord. Chem. Rev. 2016, 307, 1-31.

28. Liao, P.-Q.; He, C.-T.; Zhou, D.-D.; Zhang, J.-P.; Chen, X.-M. Porous Metal Azolate Frameworks. In The Chemistry of Metal-Organic Frameworks: Synthesis, Characterization, and Applications; Kaskel, S., Ed.; Wiley: Weinheim, Germany, 2016; Volume 1, pp. 309-343.

29. Liu, K.; Shi, W.; Cheng, P. The coordination chemistry of Zn(II), Cd(II) and Hg(II) complexes with 1,2,4-triazole derivatives. Dalton Trans. 2011, 40, 8475-8490.

30. Zhang, J.-P.; Zhang, Y.-B.; Lin, J.-B.; Chen, X.-M. Metal azolate frameworks: From crystal engineering to functional materials. Chem. Rev. 2012, 112, 1001-1033.

31. Pavlov, D.; Sukhikh, T.; Filatov, E.; Potapov, A. Facile synthesis of 3-(azol-1-yl)-1-adamantanecarboxylic acids-New bifunctional angle-shaped building blocks for coordination polymers. Molecules 2019, 24, 2717.

32. Aromí, G.; Barrios, L.A.; Roubeau, O.; Gamez, P. Triazoles and tetrazoles: Prime ligands to generate remarkable coordination materials. Coord. Chem. Rev. 2011, 255, 485-546.

33. Beckmann, U.; Brooker, S. Cobalt(II) complexes of pyridazine or triazole containing ligands: Spin-state control. Coord. Chem. Rev. 2003, 245, 17-29.

34. Klingele, M.H.; Brooker, S. The coordination chemistry of 4-substituted 3,5-di(2-pyridyl)-4H-1,2, 4-triazoles and related ligands. Coord. Chem. Rev. 2003, 241, 119-132.

35. Haasnoot, J.G. Mononuclear, oligonuclear and polynuclear metal coordination compounds with 1,2,4-triazole derivatives as ligands. Coord. Chem. Rev. 2000, 200, 131-185. 
36. Billes, F.; Endrédi, H.; Keresztury, G. Vibrational spectroscopy of triazoles and tetrazole. J. Mol. Struct. THEOCHEM 2000, 530, 183-200.

37. Nakamoto, K. Infrared and Raman Spectra of Inorganic and Coordination Compounds, 6th ed.; Part B; John Wiley \& Sons: Hoboken, NJ, USA, 2009.

38. Lever, A.B.P.; Mantovani, E.; Ramaswamy, B.S. Infrared combination frequencies in coordination complexes containing nitrate groups in various coordination environments. A probe for the metal-nitrate interaction. Can. J. Chem. 1971, 49, 1957-1964.

39. Nakamoto, K. Infrared and Raman Spectra of Inorganic and Coordination Compounds, 6th ed.; Part A; John Wiley \& Sons: Hoboken, NJ, USA, 2009.

40. Senchyk, G.A.; Lysenko, A.B.; Babaryk, A.A.; Rusanov, E.B.; Krautscheid, H.; Neves, P.; Valente, A.A.; Gonçalves, I.S.; Krämer, K.W.; Liu, S.-X.; et al. Triazolyl-based copper-molybdate hybrids: From composition space diagram to magnetism and catalytic performance. Inorg. Chem. 2014, 53, 10112-10121.

41. Senchyk, G.A.; Lysenko, A.B.; Rusanov, E.B.; Chernega, A.N.; Jezierska, J.; Domasevitch, K.V.; Ozarowski, A. Structure and magnetic behavior of $\mathrm{Cu}^{\mathrm{II}}$ MOFs supported by 1,2,4-triazolyl-bifunctionalized adamantane scaffold. Eur. J. Inorg. Chem. 2012, 2012, 5802-5813.

42. Boldog, I.; Lysenko, A.B.; Rusanov, E.B.; Chernega, A.N.; Domasevitch, K.V. 1,3,5-Triphenyladamantane and 1,3,5,7-tetraphenyladamantane. Acta Crystallogr. C 2009, 65, o248-o252.

43. Spek, A.L.J. Single-crystal structure validation with the program PLATON. J. Appl. Crystallogr. 2003, 36, 7-13.

44. Senchyk, G.A.; Lysenko, A.B.; Krautscheid, H.; Sieler, J.; Domasevitch, K.V. A dihydroxidotetracopper(II) framework supported by 4,4'-(adamantane-1,3-diyl)bis(1,2,4-triazole) and benzene-1,3,5-tricarboxylate bridges. Acta Crystallogr. C 2008, 64, m246-m249.

45. Senchyk, G.A.; Lysenko, A.B.; Krautscheid, H.; Rusanov, E.B.; Chernega, A.N.; Krämer, K.W.; Liu, S.-X.; Decurtins, S.; Domasevitch, K.V. Functionalized adamantane tectons used in the design of mixed-ligand copper(II) 1,2,4-triazolyl/carboxylate metal-organic frameworks. Inorg. Chem. 2013, 52, 863-872.

46. Senchyk, G.A.; Lysenko, A.B.; Rusanov, E.B.; Chernega, A.N.; Krautscheid, H.; Domasevitch, K.V. Polynuclear and polymeric metal complexes based upon 1,2,4-triazolyl functionalized adamantanes. Inorg. Chim. Acta 2009, 362, 4439-4448.

47. Senchyk, G.A.; Lysenko, A.B.; Naumov, D.Y.; Fedin, V.P.; Krautscheid, H.; Domasevitch, K.V. Multiple anion $\cdots \pi$ interactions with a soft selenium atom: Accommodation of $\mathrm{NCSe}^{-}$anions inside hydrophobic pockets of adamantane/1,2,4-triazole coordination framework. Inorg. Chem. Commun. 2010, 13, 1576-1579.

48. Senchyk, G.A.; Lysenko, A.B.; Boldog, I.; Rusanov, E.B.; Chernega, A.N.; Krautscheid, H.; Domasevitch, K.V. 1,2,4-Triazole functionalized adamantanes: A new library of polydentate tectons for designing structures of coordination polymers. Dalton Trans. 2012, 41, 8675-8689.

49. Lysenko, A.B.; Senchyk, G.A.; Lincke, J.; Lässig, D.; Fokin, A.A.; Butova, E.D.; Schreiner, P.R.; Krautscheid, H.; Domasevitch, K.V. Metal oxide-organic frameworks (MOOFs), a new series of coordination hybrids constructed from molybdenum(VI) oxide and bitopic 1,2,4-triazole linkers. Dalton Trans. 2010, 39, 4223-4231.

50. Lysenko, A.B.; Senchyk, G.A.; Domasevitch, K.V.; Hauser, J.; Fuhrmann, D.; Kobalz, M.; Krautscheid, H.; Neves, P.; Valente, A.A.; Goncalves, I.S. Synthesis and structural elucidation of triazolylmolybdenum(VI) oxide hybrids and their behavior as oxidation catalysts. Inorg. Chem. 2015, 54, 8327-8338.

51. Senchyk, G.A.; Lysenko, A.B.; Krautscheid, H.; Domasevitch, K.V. Fluoride molecular scissors: A rational construction of new Mo(VI) oxofluorido/1,2,4-triazole MOFs. Inorg. Chem. Commun. 2011, 14, 1365-1368.

52. Muñoz-Lara, F.J.; Gaspar, A.B.; Muñoz, M.C.; Lysenko, A.B.; Domasevitch, K.V.; Real, J.A. Fast detection of water and organic molecules by a change of color in an iron(II) microporous spin-crossover coordination polymer. Inorg. Chem. 2012, 51, 13078-13080.

53. Senchyk, G.A.; Bukhan'ko, V.O.; Lysenko, A.B.; Krautscheid, H.; Rusanov, E.B.; Chernega, A.N.; Karbowiak, M.; Domasevitch, K.V. $\mathrm{Ag}^{\mathrm{I}} / \mathrm{V}^{\mathrm{V}}$ heterobimetallic frameworks generated from novel-type $\left.\left\{\mathrm{Ag}_{2}\left(\mathrm{VO}_{2} \mathrm{~F}_{2}\right)_{2} \text { (triazole }\right)_{4}\right\}$ secondary building blocks: A new aspect in the design of SVOF hybrids. Inorg. Chem. 2012, 51, 8025-8033.

54. Sheldrick, G.M. A short history of SHELX. Acta Crystallogr. A 2008, 64, 112-122.

55. Sheldrick, G.M. Crystal structure refinement with SHELXL. Acta Crystallogr. C 2015, 71, 3-8.

56. Coelho, A.A. Indexing of powder diffraction patterns by iterative use of singular value decomposition. J. Appl. Crystallogr. 2003, 36, 86-95.

57. Topas-R, V3; Bruker AXS: Karlsruhe, Germany, 2005. 
58. Coelho, A.A. Whole-profile structure solution from powder diffraction data using simulated annealing. J. Appl. Crystallogr. 2000, 33, 899-908.

59. Rietveld, H.M. A profile refinement method for nuclear and magnetic structures. J. Appl. Crystallogr. 1969, 2, 65-71.

60. Cheary, R.W.; Coelho, A.A. A fundamental parameters approach to X-ray line-profile fitting. J. Appl. Crystallogr. 1992, 25, 109-121.

61. Dollase, W.A. Correction of intensities for preferred orientation in powder diffractometry: Application of the March model. J. Appl. Crystallogr. 1986, 19, 267-272.

Publisher's Note: MDPI stays neutral with regard to jurisdictional claims in published maps and institutional affiliations.

(C) 2020 by the authors. Licensee MDPI, Basel, Switzerland. This article is an open access article distributed under the terms and conditions of the Creative Commons Attribution (CC BY) license (http://creativecommons.org/licenses/by/4.0/). 